\title{
Alfalfa cut at sundown and harvested as baleage increases bacterial protein synthesis in late-lactation dairy cows ${ }^{1}$
}

\author{
A. F. Brito, ${ }^{\star}$ G. F. Tremblay, $\dagger$ H. Lapierre, ${ }^{\star}$ A. Bertrand, $\dagger$ Y. Castonguay, $\dagger$ G. Bélanger, $\dagger$ R. Michaud, $\dagger$ \\ C. Benchaar, ${ }^{\star}$ D. R. Ouellet, ${ }^{\star}$ and R. Berthiaume ${ }^{\star 2}$ \\ *Dairy and Swine Research and Development Centre, Agriculture and Agri-Food Canada, Sherbrooke, Québec, Canada J1M 1 Z3 \\ †Soils and Crops Research and Development Centre, Agriculture and Agri-Food Canada, Québec, Québec, Canada G1V 2J3
}

\begin{abstract}
Alfalfa (Medicago sativa L.) cut at sundown (p.m.) has been shown to have a greater concentration of total nonstructural carbohydrates (TNC) than when cut at sunup (a.m.). Eight ruminally cannulated Holstein cows that were part of a larger lactation trial were used in a crossover design (24-d periods) to investigate the effects of alfalfa cutting time on digestibility and omasal flow of nutrients. Alfalfa was cut at sundown or sunup, field-wilted, and harvested as baleage (530 \pm $15.0 \mathrm{~g}$ of dry matter $/ \mathrm{kg}$ of fresh matter). The difference in TNC concentration between p.m. and a.m. alfalfa within each pair of bales fed daily during the $10 \mathrm{~d}$ of data and sample collection varied from -10 to $50 \mathrm{~g} /$ $\mathrm{kg}$ of dry matter. Each pair of bales was fed for ad libitum intake to cows once daily with no concentrate. During the $3 \mathrm{~d}$ of omasal sampling, intake $(+0.8 \mathrm{~kg} / \mathrm{d})$ and omasal flow of organic matter $(\mathrm{OM} ;+0.42 \mathrm{~kg} / \mathrm{d})$ tended to be greater when cows were fed p.m. vs. a.m. alfalfa, but no differences were found for ruminal and postruminal digestion of this nutrient. Similarly, N apparently digested ruminally and postruminally did not differ when feeding p.m. vs. a.m. alfalfa. However, $\mathrm{N}$ truly digested in the rumen, as a proportion of $\mathrm{N}$ intake, was significantly greater in cows fed p.m. (79\%) vs. a.m. alfalfa (74\%), thus suggesting that longer wilting time of alfalfa cut at sundown increased forage proteolysis. Supply of rumen-degradable protein did not change $(2,716 \mathrm{~g} / \mathrm{d})$ when averaged across treatments, whereas omasal flow of non- $\mathrm{NH}_{3}$ nonbacterial $\mathrm{N}$ was significantly decreased $(-29 \mathrm{~g} / \mathrm{d})$ when feeding p.m. vs. a.m. alfalfa. Omasal flow of total bacterial non- $\mathrm{NH}_{3}$ $\mathrm{N}(\mathrm{NAN})$ increased $(+21 \mathrm{~g} / \mathrm{d})$ significantly when cows were fed p.m. vs. a.m. alfalfa possibly because bacteria from cows fed p.m. alfalfa captured significantly more
\end{abstract}

Received June 20, 2008

Accepted October 27, 2008.

${ }^{1}$ Contribution no. 976 from the Dairy and Swine Research and Development Centre.

${ }^{2}$ Corresponding author: berthiaumer@agr.gc.ca
$\mathrm{NH}_{3}$ than those from cows fed a.m. alfalfa. Therefore, greater availability of fermentable energy as TNC appears to increase the capacity of microbes to uptake $\mathrm{NH}_{3}-\mathrm{N}$ and convert it to microbial protein. Enhanced OM intake can also explain the observed increase in bacterial protein synthesis with p.m. alfalfa. Efficiency of bacterial protein synthesis, expressed on a fermented OM basis or as grams of bacterial NAN per gram of rumen-degradable $\mathrm{N}$, did not differ between p.m. and a.m. alfalfa. Conversely, bacterial efficiency, as grams of bacterial NAN per gram of $\mathrm{N}$ intake, was significantly increased when cows were fed p.m. baleage. No significant difference between forage treatments was found for the omasal flow of total AA from omasal true digesta, suggesting no benefit of daytime cutting management on the passage of total AA to the lower gastro-intestinal tract. Enhancing energy intake and TNC concentration of alfalfa by shifting forage cutting from sunup to sundown increased protein synthesis and $\mathrm{NH}_{3}$ uptake by ruminal bacteria indicating an improvement in $\mathrm{N}$ utilization.

Key words: alfalfa diurnal cutting, bacterial protein synthesis, dairy cow, total nonstructural carbohydrate

\section{INTRODUCTION}

Several studies have shown that the concentration of total nonstructural carbohydrates (TNC) is greater in grasses (Fisher et al., 1999; Huntington and Burns, 2007) and legumes (Fisher et al., 2002; Burns et al., 2005, 2007; Brito et al., 2008) cut at sundown than sunup because of the plant potential to accumulate carbohydrates during the photoperiod. Sixteen latelactation dairy cows receiving baleages harvested from alfalfa cut at sundown (p.m.) or sunup (a.m.) had increased DMI $(+1.0 \mathrm{~kg} / \mathrm{d})$, milk $(+1.0 \mathrm{~kg} / \mathrm{d})$, milk fat $(+70 \mathrm{~g} / \mathrm{d})$, milk protein $(+40 \mathrm{~g} / \mathrm{d})$, and milk $\mathrm{N}$ efficiency $(+8 \%)$ but decreased $(-10 \%)$ MUN (Brito et al., 2008). Therefore, ruminal microbes might have benefited from the superior concentration of TNC from p.m. compared with a.m. alfalfa yielding more microbial protein, which would explain the improvements in 
milk production and $\mathrm{N}$ utilization (Brito et al., 2008). Previous in vivo (Lee et al., 2002) and in vitro (Berthiaume et al., 2007) studies showed that bacterial N flow was increased by 27 and $14 \%$, respectively, when steers and dual-flow continuous culture fermenters were fed forages with elevated concentrations of water-soluble carbohydrates (WSC) and starch. In addition, ruminal $\mathrm{NH}_{3}-\mathrm{N}$ decreased with feeding high-WSC diets (Lee et al., 2002), indicating that the efficiency of utilization of $\mathrm{NH}_{3}$ by ruminal microbes was enhanced when more fermentable sugars were available in the rumen. It is important to note that in vitro DM digestibility was also greater with high- $(61 \%)$ vs. low-WSC $(56 \%)$ perennial ryegrass (Lolium perenne L.) in the study of Lee et al. (2002), suggesting that WSC were not the sole source of fermentable energy available to the microbes. However, data from the present study reported earlier revealed that the concentration of ruminal $\mathrm{NH}_{3}-\mathrm{N}$ did not differ between cows fed p.m. vs. a.m. alfalfa (Brito et al., 2008). This apparent discrepancy could be related to the effect of cutting management on the protein fractions of alfalfa. Cutting alfalfa at sundown increased wilting time (+18 h; Brito et al., 2008), which is known to enhance proteolysis (Papadopoulos and McKersie, 1983). Therefore, p.m.-cut alfalfa would contain more RDP than a.m.-cut alfalfa, resulting in a similar concentration of ruminal $\mathrm{NH}_{3}$ despite the greater content of TNC in the former compared with the latter forage.

We hypothesized in the current study that feeding p.m. vs. a.m. alfalfa (high vs. low TNC) would stimulate microbial growth and yield due to increased availability of fermentable energy in the rumen, which could explain the increases in the yields of milk and milk protein previously reported (Brito et al., 2008). It was also hypothesized that more microbial protein synthesis with feeding p.m.-cut alfalfa baleage would enhance the passage of essential AA (EAA) to the small intestine leading to an increase in milk production because of the improved AA profile of protein from ruminal microbes than RUP from alfalfa. The objectives of this study were to compare the effects of feeding p.m. vs. a.m. alfalfa baleage on ruminal and postruminal digestibility of nutrients, bacterial protein synthesis, and omasal flow of AA and nutrients.

\section{MATERIALS AND METHODS}

\section{Harvest of Alfalfa and Animals}

The alfalfa cultivar AC Caribou (La Coop Fédérée, Montréal, Québec, Canada) used in the present study grew in 3 well-established fields (total of 14 ha) located at the Normandin Research Farm of Agriculture and Agri-Food Canada $\left(48^{\circ} 51^{\prime} \mathrm{N}, 72^{\circ} 32^{\prime} \mathrm{W}\right)$ in the province of Québec, Canada. The spring growth of half of each field was cut after a sunny day on June 12, 2006 at sundown (between 1830 and 2145 h; p.m. alfalfa), whereas the second half was cut on June 13, 2006 at sunup (between 0630 and 1030 h; a.m. alfalfa) at the late bud stage of development. Forage was cut using a conventional mower conditioner, tedded, and fieldwilted to about $531 \mathrm{~g} / \mathrm{kg}$ of DM, which was attained after approximately 48 and $30 \mathrm{~h}$ of field-drying for p.m. and a.m. alfalfa, respectively. Between 1300 and $1600 \mathrm{~h}$ in the afternoon of June 14, 2006, p.m. and then a.m. alfalfa were harvested as baleages using a large rectangular baler (New Idea model 7333, AGCO Corporation, Duluth, GA) and wrapped with stretch plastic using a bale wrapper (Équipement Anderson model 680-S, Chesterville, Québec, Canada). A total of 148 bales (72 p.m. and 76 a.m.) were made and later transported to the Dairy and Swine Research and Development Centre of Agriculture and Agri-Food Canada located in Sherbrooke $\left(45^{\circ} 24^{\prime} \mathrm{N}, 71^{\circ} 54^{\prime} \mathrm{W}\right)$, Québec, Canada, for the animal study. Three weeks before the beginning of the trial, a sample of approximately $200 \mathrm{~g}$ of baleage was collected from each bale using an electrical drill fitted with a metal core bale sampler, dried at $55^{\circ} \mathrm{C}$ for $48 \mathrm{~h}$ (forced-air oven), ground to pass through a 1-mm screen (Wiley mill, Arthur H. Thomas, Philadelphia, PA), and individually analyzed for total soluble carbohydrates (reducing sugars), starch, and pinitol as described previously (Brito et al., 2008). Pinitol is a cyclitol nonreducing sugar (Streeter et al., 2001) found in several legume species (Smith and Phillips, 1980) and possibly involved in helping plants to survive against adverse environmental conditions (McManus et al., 2000; Streeter et al. 2001) including freezing stress in alfalfa (Bertrand et al., 2007). Water-soluble carbohydrates were obtained by combining reducing sugars and pinitol, whereas TNC were calculated as the sum of WSC and starch (Table 1). It is important to note that pectin is not included in the computation of TNC but its precursor galacturonic acid is because it reacts with the colorimetric method described in Brito et al. (2008). The p.m. and a.m. bales were carefully identified and ranked according to their TNC concentration within each treatment (p.m. and a.m.) going from the greatest to the lowest TNC content. Next, the p.m. and a.m. bales with the greatest TNC concentrations were paired and this procedure repeated for the remaining 94 bales leading to the formation of a total of 48 pairs that were randomly assigned to each of the 48 experimental days. The objective of ranking and pairing was to obtain a greater concentration of TNC in p.m. vs. a.m. bales and to maintain, as much as possible, a consistent difference in TNC between treatments throughout the trial. The difference in TNC concentration between 
Table 1. Nonstructural carbohydrate composition of baleages harvested from alfalfa cut at sundown (p.m.) or sunup (a.m.)

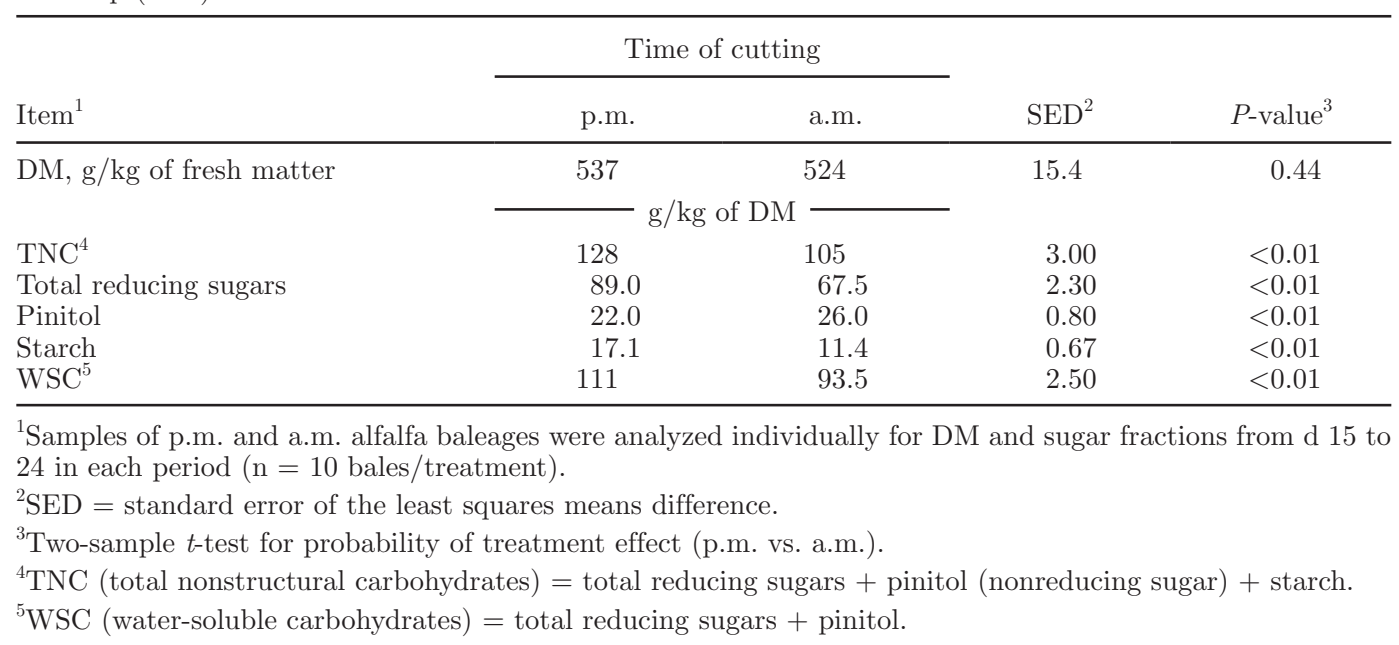

p.m. and a.m. alfalfa, within each pair of bales, fed during the $10 \mathrm{~d}$ of data and sample collection varied from -10 to $50 \mathrm{~g} / \mathrm{kg}$ of DM with a mean value of 23 $\mathrm{g} / \mathrm{kg}$ of DM. Each pair of bales was fed for ad libitum intake to the cows once daily at approximately $0800 \mathrm{~h}$. A vitamin and mineral premix was top-dressed daily on the forage at feeding, but no concentrate was fed to the animals. In this study, which was part of a larger lactation trial (Brito et al., 2008), we used 8 ruminally cannulated multiparous Holstein cows averaging (mean $\pm \mathrm{SD}) 134 \pm 68 \mathrm{DIM}$ and $649 \pm 45 \mathrm{~kg}$ of BW. Cows were blocked by DIM and, within each block, randomly assigned to 2 forage treatments (p.m. vs. a.m. alfalfa) in a crossover design. Each period lasted $24 \mathrm{~d}$ and consisted of $14 \mathrm{~d}$ for diet adaptation and $10 \mathrm{~d}$ for data and sample collection. Other details of this trial were described previously by Brito et al. (2008), in which we reported the effects of p.m. vs. a.m. cutting on $\mathrm{N}$ utilization and milk production of 16 late-lactation dairy cows. Care and handling of the animals were conducted as outlined in the guidelines of the Canadian Council on Animal Care (1993), and the study was approved by the Institutional Animal Care Committee of the Dairy and Swine Research and Development Centre.

\section{Digestive Tract Sampling and Analyses}

Spot samples of omasal digesta leaving the rumen were collected through the omasal orifice from the 8 ruminally cannulated cows using the omasal sampling technique developed by Huhtanen et al. (1997) and Ahvenjärvi et al. (2000), as adapted by Reynal et al. (2003). The following omasal digesta markers were used: indigestible NDF (Huhtanen et al., 1994) for the large particle phase $(\mathbf{L P}), \mathrm{YbCl}_{3}$ (modified from Sid- dons et al., 1985) for the small particle phase (SP), and Co-EDTA (Udén et al., 1980) for the fluid phase (FP). A marker solution containing $\mathrm{YbCl}_{3}$, Co-EDTA, and ${ }^{15} \mathrm{NH}_{4} \mathrm{SO}_{4}$ with 10 atom percentage excess (APE) ${ }^{15} \mathrm{~N}$ (Isotec, Miamisburg, $\mathrm{OH}$ ) was prepared as described by Reynal and Broderick (2005). A sample of $500 \mathrm{~mL}$ of omasal digesta (background) was taken from each cow before the beginning of the infusion of markers to determine the natural abundance of ${ }^{15} \mathrm{~N}$. Cows were then prime-dosed with $3.0 \mathrm{~L}$ of the same markers solution used during the continuous infusion. Cobalt-EDTA, $\mathrm{YbCl}_{3}$, and ${ }^{15} \mathrm{NH}_{4} \mathrm{SO}_{4}$ were continuously infused into the rumen from d 11 to 17 (157 h of infusion) using 4 peristaltic pumps (Masterflex L/S model no. 752350, Cole-Parmer Instrument Co., Barrington, IL) at a constant rate of $3.11 \mathrm{~L} / \mathrm{d}$ providing $2.54 \mathrm{~g}$ of $\mathrm{Co}, 3.41$ $\mathrm{g}$ of $\mathrm{Yb}$, and $0.25 \mathrm{~g}$ of ${ }^{15} \mathrm{~N}$ per day. Omasal sampling was initiated approximately $87 \mathrm{~h}$ after beginning the markers infusion with samples taken 4 times daily at 2-h intervals during 3 consecutive days to represent the 24-h feeding cycle: 0000, 0200, 0400, and $0600 \mathrm{~h}$ on d $15 ; 0800,1000,1200$, and $1400 \mathrm{~h}$ on $\mathrm{d} 16$; and 1600 , 1800,2000 , and $2200 \mathrm{~h}$ on d 17 . The omasal sampling tube was kept inserted into the reticulo-omasal orifice for the entire collection of omasal digesta, which lasted approximately $7 \mathrm{~h} / \mathrm{d}$. However, before each sampling point, it was necessary to confirm the location of the sampling tube and occasionally it had to be repositioned into the omasal canal. Sometimes it was also necessary to unplug the holes in the end of the sampling tube because of the presence of coarse digesta. At each of the 4 daily sampling times, a 550-mL spot sample of omasal digesta was collected and split under continuous mechanical agitation into 3 subsamples of 100,400 , and 50 $\mathrm{mL}$. The 4 daily $100-\mathrm{mL}$ subsamples were pooled and 
stored on ice inside a refrigerator $\left(4^{\circ} \mathrm{C}\right)$ for the duration of omasal digesta collection (approximately $7 \mathrm{~h}$ ). These 4 daily $100-\mathrm{mL}$ subsamples were pooled into a single composite of $400 \mathrm{~mL}$ per cow that was transported to the laboratory for bacterial isolation. Therefore, a total of 3 composites of $400 \mathrm{~mL}$ were obtained over the 3 sampling days for each cow in each period. The 4 daily $400-\mathrm{mL}$ subsamples were stored at $-20^{\circ} \mathrm{C}$ and pooled over $3 \mathrm{~d}$ to obtain a single 4.8-L composite from each cow in each period for later separation into the 3 omasal phases (LP, SP, and FP). The remaining 50-mL subsample of omasal digesta was squeezed through 2 layers of cheesecloth with $10 \mathrm{~mL}$ of the filtrate pipeted into a plastic container followed by the addition of 0.2 $\mathrm{mL}$ of concentrated $\mathrm{H}_{2} \mathrm{SO}_{4}$. The 4 daily $10-\mathrm{mL}$ filtrates were stored at $-20^{\circ} \mathrm{C}$ and pooled over $3 \mathrm{~d}$ to obtain a single $120-\mathrm{mL}$ composite from each cow in each period for later analysis of ${ }^{15} \mathrm{~N}$ enrichment of $\mathrm{NH}_{3}$.

At the end of each sampling day, the 400-mL omasal composites were squeezed through 1 layer of cheesecloth. The solids retained on the cheesecloth (equivalent to LP) were washed with $400 \mathrm{~mL}$ of $0.85 \%$ (wt/vol) $\mathrm{NaCl}$ solution and squeezed again; filtrates (equivalent to the FP) were pooled and held on ice until processed for isolation of fluid-associated bacteria (FAB). The solids retained on the cheesecloth were transferred to a $500-\mathrm{mL}$ bottle, to which $350 \mathrm{~mL}$ of a cold $\left(5^{\circ} \mathrm{C}\right)$ solution containing $0.85 \%$ (wt/vol) $\mathrm{NaCl}$ plus $0.1 \%$ (wt/ vol) Tween-80 was added. Bottle contents were mixed thoroughly and held on ice until processed for isolation of particle-associated bacteria (PAB). Filtrates for $\mathrm{FAB}$ isolation were centrifuged $\left(1,000 \times g, 5^{\circ} \mathrm{C}, 5\right.$ min) and the pellets were added to the bottles to be used for PAB isolation. Supernatants were carefully decanted and centrifuged at greater speed $(11,300 \times$ $\left.g, 5^{\circ} \mathrm{C}, 30 \mathrm{~min}\right)$; these supernatants were decanted and discarded. Pellets were resuspended in $100 \mathrm{~mL}$ of McDougall's buffer (McDougall, 1948) and recentrifuged $\left(11,300 \times g, 5^{\circ} \mathrm{C}, 30 \mathrm{~min}\right)$. The resulting FAB pellets were stored at $-20^{\circ} \mathrm{C}$ until freeze-dried and ground with a mortar and pestle for later analyses. Contents of the PAB bottles were blended for $20 \mathrm{~s}$ in a 1-speed Waring blender (Waring Products Division, New Hartford, CT), transferred back to the bottles, and stored at $5^{\circ} \mathrm{C}$. After $24 \mathrm{~h}$ inside a refrigerator at $5^{\circ} \mathrm{C}$, contents were squeezed through 2 layers of cheesecloth and the filtrates were centrifuged $\left(1,000 \times g, 5^{\circ} \mathrm{C}, 5 \mathrm{~min}\right)$; supernatants were carefully decanted and pellets discarded. Supernatants were centrifuged at greater speed $(11,300$ $\times g, 5^{\circ} \mathrm{C}, 30 \mathrm{~min}$ ), decanted and discarded, and the pellets resuspended in $100 \mathrm{~mL}$ of McDougall's buffer and recentrifuged $\left(11,300 \times g, 5^{\circ} \mathrm{C}, 30 \mathrm{~min}\right)$. The resulting PAB pellets were stored at $-20^{\circ} \mathrm{C}$ until freeze-dried and ground with a mortar and pestle for later analyses.
The 4.8-L composite digesta samples were thawed at room temperature and separated into 3 omasal digesta phases as follows. Samples were squeezed through 1 layer of cheesecloth, and the retained solids were defined as the omasal LP. The filtrate was centrifuged at $1,000 \times g\left(5^{\circ} \mathrm{C}, 5 \mathrm{~min}\right)$ and the supernatant carefully decanted from the pellet. The supernatant was defined as the FP, whereas the pellet was defined as the SP. The separated phases were frozen $\left(-20^{\circ} \mathrm{C}\right)$, freeze-dried, ground through a 1-mm screen (Wiley mill), and then analyzed for $\mathrm{Co}$ and $\mathrm{Yb}$ according to Siddons et al. (1985). Briefly, 0.5-g samples of LP, SP, and $\mathrm{FP}$ were ashed at $550^{\circ} \mathrm{C}$ for $16 \mathrm{~h}$ in a muffle furnace. Then, $3 \mathrm{~mL}$ of a $\mathrm{H}_{3} \mathrm{PO}_{4}: \mathrm{MnSO}_{4}$ solution $(30 \mathrm{~mL}$ of $7.58 \%$ wt/vol $\mathrm{MnSO}_{4}$ into $1 \mathrm{~L}$ of $85 \% \mathrm{H}_{3} \mathrm{PO}_{4}$ ) was carefully added to each beaker followed by the addition of $4 \mathrm{~mL}$ of a $4.5 \%$ (wt/vol) $\mathrm{BrKO}_{3}$ solution. Beakers were covered with watch glasses and digested under the hood on a heated plate until effervescence ceased (approximately $20 \mathrm{~min}$ ). After cooling down for $30 \mathrm{~s}, 6$ $\mathrm{mL}$ of a $\mathrm{CaCl}_{2}$ solution (14.7 $\mathrm{g}$ of $\mathrm{CaCl}_{2}$ in $1 \mathrm{~L}$ of double distilled water) was added to each beaker, the content was transferred to $50-\mathrm{mL}$ screw-cap plastic tubes (Sarstedt AG \& Co., Nümbrecht, Germany), and the volume was completed with double-distilled water to a final mass of $50 \mathrm{~g}$. Concentrations of $\mathrm{Co}$ and $\mathrm{Yb}$ were determined by atomic absorption spectroscopy with an air-acetylene flame (Perkin-Elmer model AAnalyst 300, Perkin-Elmer Instruments LCC, Waltham, MA). Indigestible NDF was determined in LP, SP, and alfalfa baleages but not in FP (Ahvenjärvi et al., 2000). Samples of LP and alfalfa (1 g each) were weighed into duplicate, whereas those of SP $(1 \mathrm{~g})$ into triplicate $5 \times$ $10 \mathrm{~cm}$ bags made of $6-\mu \mathrm{m}$ pore size nylon mesh (part no. 03-6/5, Sefar America Inc., Depew, NY) and then incubated in the rumen of 1 ruminally cannulated cow for 12 d. Bags were then placed in an ice batch to stop microbial activity, rinsed with tap water to remove coarse ruminal digesta, washed in a washing machine (5 cycles of $10 \mathrm{~min}$ ), and later analyzed for NDF as described previously (Brito et al., 2008). Marker concentrations were used to physically recombine DM from the freeze-dried FP, SP, and LP in the correct proportions to reconstitute the omasal true digesta (OTD) flowing out of the rumen according to the triple-marker method of France and Siddons (1986). Concentration of each digesta marker was distinctly greater in the omasal digesta phase (with which the marker is mainly associated) than in the other 2 phases, thus allowing for successful application of the triple-marker method. Dry matter from SP and LP was also physically recombined in correct proportions based on the digesta markers to yield a 2-g sample that was ground through a $0.5-\mathrm{mm}$ screen (Marathon Electric mill, Wausau, WI) and de- 
fined as particle phase (PF). Samples of background omasal digesta $(500 \mathrm{~mL})$ were freeze-dried and ground to pass through both a 1-mm (Wiley mill) and then a 0.5-mm screen (Marathon Electric mill).

Omasal true digesta samples were analyzed for analytical $\mathrm{DM}\left(105^{\circ} \mathrm{C}\right)$, ash, total $\mathrm{N}, \mathrm{NDF}$, and $\mathrm{AA}$ as described previously (Brito et al., 2008). Extracts were also prepared from OTD samples as follows: 10 $\mathrm{mL}$ of $\mathrm{pH} 2.2$ Na-citrate buffer was added to $0.5 \mathrm{~g}$ of dried samples and then vortexed. After standing for $30 \mathrm{~min}$ in a forced-air oven at $39^{\circ} \mathrm{C}$, extracts were centrifuged at $15,000 \times g$ for $15 \mathrm{~min}$ at $4^{\circ} \mathrm{C}$, and the supernatants were stored at $-20^{\circ} \mathrm{C}$ for later analysis of $\mathrm{NH}_{3}$ as reported earlier (Brito et al., 2008). Samples of $\mathrm{FAB}, \mathrm{PAB}, \mathrm{PF}$, and background omasal digesta were prepared for NAN and ${ }^{15} \mathrm{~N}$ analyses as follows: approximately $100 \mu \mathrm{g}$ of $\mathrm{N}$ from each sample was weighed into tin capsules (Elemental Microanalysis Limited, Okehampton, UK), placed in 96-well microtiter plates, treated with $50 \mu \mathrm{L}$ of $72 \mathrm{mM} \mathrm{K} \mathrm{CO}_{3}$, and finally dried at $60^{\circ} \mathrm{C}$ (forced-air oven) for $24 \mathrm{~h}$ to volatilize $\mathrm{NH}_{3}$. Tin capsules containing samples were folded using tweezers and sent to the Stable Isotope Facility of the University of California-Davis for analyses of NAN and ${ }^{15} \mathrm{~N}$ with a PDZ Europa ANCA-GSL elemental analyzer interfaced to a PDZ Europa 20-20 isotope ratio mass spectrometer (Sercon Ltd., Cheshire, UK). Bacterial samples (PAB and $\mathrm{FAB}$ ) were also analyzed for analytical DM (overnight at $\left.105^{\circ} \mathrm{C}\right)$, ash $\left(16 \mathrm{~h}\right.$ at $\left.550^{\circ} \mathrm{C}\right)$, and $\mathrm{AA}$ (Brito et al., 2008).

Fecal grab samples were collected from the 8 cows at the time of omasal sampling. Samples were pooled based on weight $(100 \mathrm{~g})$ over the $3 \mathrm{~d}$ to obtain a single composite and then freeze-dried. Dried samples were ground to pass through a 1-mm screen (Wiley mill) and analyzed for analytical DM, ash, total N, and NDF as described previously (Brito et al., 2008). Fecal samples $(2 \mathrm{~g})$ were prepared and analyzed for $\mathrm{Yb}$ concentration using the same methodology described for the 3 omasal phases. Ytterbium was used as an external marker to estimate fecal output of DM (Cochran et al., 1986).

\section{Calculations}

Mean intakes of nutrients reported in this study were measured during the $3 \mathrm{~d}$ of omasal sampling, unless otherwise stated. Omasal flow of NAN was determined by difference between total $\mathrm{N}$ and $\mathrm{NH}_{3}-\mathrm{N}$ flows. Total NAN flowing past the omasal canal was assumed to be composed of PAB NAN, FAB NAN, plus non- $\mathrm{NH}_{3}$ nonbacterial N (NANBN). The natural abundance $( \pm \mathrm{SD})$ of ${ }^{15} \mathrm{~N}$ in samples from background omasal digesta averaged $0.36795( \pm 0.00029)$ atom percentage across cows in the 2 experimental periods. Enrichment of ${ }^{15} \mathrm{~N}$ was defined as ${ }^{15} \mathrm{~N}$ APE above the natural abundance of ${ }^{15} \mathrm{~N}$ measured in background omasal digesta samples, and it was calculated as follows:

$$
\begin{gathered}
{ }^{15} \mathrm{~N} \text { APE }\left({ }^{15} \mathrm{~N} \text { enrichment }\right)={ }^{15} \mathrm{~N} \text { atom } \% \\
\text { - background }{ }^{15} \mathrm{~N} \text { atom } \% .
\end{gathered}
$$

Assuming that FAB and PAB were representative of bacteria flowing with the FP and the PF, respectively, omasal flows of FAB NAN, PAB NAN, and total bacterial NAN were calculated as follows:

$$
\begin{array}{r}
\text { FAB NAN flow }=\text { FP NAN flow } \\
\times\left(\mathrm{FP}^{15} \mathrm{~N} \text { APE } \div \mathrm{FAB}^{15} \mathrm{~N} \text { APE }\right) \\
\text { PAB NAN flow }=\text { PF NAN flow } \\
\times\left(\mathrm{PF}^{15} \mathrm{~N} \text { APE } \div \text { PAB }{ }^{15} \mathrm{~N} \text { APE }\right)
\end{array}
$$

Total bacterial NAN flow $=$ FAB NAN flow + PAB NAN flow.

Omasal flow of NANBN, RDP supply, and OM truly digested in the rumen (OMTDR) were calculated as follows:

$$
\begin{aligned}
& \text { NANBN flow }=\text { total NAN flow } \\
& - \text { total bacterial NAN flow } \\
& \text { RDP supply }=\text { total CP intake } \\
& -(\text { NANBN flow } \times 6.25)
\end{aligned}
$$

$\mathrm{FAB}$ or $\mathrm{PAB} \mathrm{DM}$ flow $=\mathrm{FAB}$ or PAB NAN flow

$$
\div(\% \text { FAB or PAB NAN } \div 100)
$$

$\mathrm{FAB}$ or $\mathrm{PAB} \mathrm{OM}$ flow $=(\mathrm{FAB}$ or $\mathrm{PAB} \mathrm{DM}$ flow

$$
\times \% \text { FAB or } \mathrm{PAB} \text { OM }) \div 100
$$

$$
\begin{aligned}
& \text { Total bacterial OM flow }=\text { FAB OM flow } \\
& + \text { PAB OM flow } \\
& \text { OMTDR }=\text { OM intake }- \text { (omasal OM flow } \\
& - \text { total bacterial OM flow }),
\end{aligned}
$$

where flows and intakes are in grams per day or kilograms per day and NAN concentrations are in grams per gram of OM. 
Table 2. Chemical composition of baleages harvested from alfalfa cut at sundown (p.m.) or sunup (a.m.)

\begin{tabular}{lcc}
\hline & \multicolumn{2}{c}{ Time of cutting } \\
\cline { 2 - 3 } Item $^{1}$ & $\mathrm{p} . \mathrm{m}$. & $\mathrm{a} . \mathrm{m}$. \\
\hline & & $\mathrm{g} / \mathrm{kg}$ of DM \\
\cline { 2 - 3 } Ash & 113 & 117 \\
CP & 179 & 189 \\
NPN & & 89.0 \\
NDIN & 90.0 & 3.72 \\
ADIN & 3.40 & 1.07 \\
NDF & 0.97 & 408 \\
ADF & 391 & 302 \\
Essential AA & 287 & \\
His & & 2.50 \\
Ile & 1.98 & 5.99 \\
Leu & 5.77 & 10.8 \\
Lys & 10.4 & 8.02 \\
Met & 7.50 & 2.87 \\
Phe & 2.77 & 6.94 \\
Thr & 6.59 & 6.82 \\
Val & 6.27 & 7.14 \\
Total & 6.86 & 58.1 \\
Total NEAA & 48.1 & 43.0 \\
Total AA & 39.4 & 94.0 \\
\hline
\end{tabular}

${ }^{1}$ Samples of p.m. and a.m. alfalfa baleages used for the chemical analyses of variables presented in this table were pooled from d 15 to 24 in each period. Therefore, standard errors and statistical analyses cannot be provided.

${ }^{2} \mathrm{NPN}=$ soluble $\mathrm{N}$ in TCA solution $\times 6.25$ (Licitra et al., 1996).

${ }^{3} \mathrm{NDIN}=$ neutral detergent insoluble $\mathrm{N}$.

${ }^{4} \mathrm{NEAA}=$ nonessential AA.

\section{Statistical Analyses}

Data were analyzed using the MIXED procedure of SAS (SAS Institute, 1999-2000) for a crossover design according to the following model:

$$
\mathrm{Y}_{\mathrm{ijkl}}=\mu+\mathrm{S}_{\mathrm{i}}+\mathrm{C}_{\mathrm{j}}(\mathrm{S})_{\mathrm{i}}+\mathrm{P}_{\mathrm{k}}+\mathrm{T}_{1}+\mathrm{E}_{\mathrm{ijkl}} \text {, }
$$

where $\mathrm{Y}_{\mathrm{ijkl}}=$ dependent variable; $\mu=$ overall mean; $\mathrm{S}_{\mathrm{i}}=$ mean effect of the ith crossover sequence group; $\mathrm{C}_{\mathrm{j}}(\mathrm{S})_{\mathrm{i}}=$ mean effect of $\mathrm{jth}$ cow nested within ith sequence; $\mathrm{P}_{\mathrm{k}}=$ mean effect of kth period; $\mathrm{T}_{1}=$ mean effect of the lth treatment; and $\mathrm{E}_{\mathrm{ijk}}=$ random residual variation. All terms were considered fixed except $\mathrm{C}_{\mathrm{j}}(\mathrm{S})$ ${ }_{i}$ and $E_{i j k l}$ that were considered random. All reported values are LSM. Significance was declared at $P \leq 0.05$ and trends at $0.05<P \leq 0.10$.

\section{RESULTS AND DISCUSSION}

\section{Alfalfa Chemical Composition and Animal Performance}

A detailed discussion of the effects of daytime cutting management (p.m.- vs. a.m.-cut) on chemical composi- tion of alfalfa baleages and on animal performance of 16 late-lactation cows is reported elsewhere (Brito et al., 2008). The chemical composition of baleages fed to the cows is presented on Tables 1 and 2 . In the current paper, we will discuss the variation of baleage TNC throughout the 48-d trial (Figure 1) and briefly discuss the effects of feeding p.m. vs. a.m. alfalfa on feed intake and milk production and composition of 8 ruminally cannulated cows (Table 3).

The TNC concentration varied across baleages during the 48-d study as shown in Figure 1. Although alfalfa was harvested from 3 well-established fields, variation in plant chemical composition within field and across fields is expected. Moreover, management factors including moisture level, bale density, and integrity of the plastic wrapping may also affect the fermentation and subsequent baleage quality. Even properly harvested baleage can be extremely inconsistent in quality compared with silage because the absence of surrounding forage mass results in a greater exposition of the harvested material when it is stored in a bale rather than in a silo. Therefore, the chemical composition of baleage is expected to vary from one bale to the next because, in a sense, every bale is a single smallscale silo. Knowing that baleage is prone to variation in chemical composition, we decided to rank and pair the bales to feed baleages with a somewhat constant difference in TNC concentration throughout the study. In fact, we were able to feed p.m. baleages with greater TNC concentration than a.m. baleages in 46 out of 48 $\mathrm{d}$ of the experiment (Figure 1). However, on few occasions during the trial, bales $(n=4)$ had to be discarded due to mold contamination, which changed the initial preplanned pairing. As a result, on the last $2 \mathrm{~d}$ of period 2 (d 23 and 24), the TNC concentration of p.m. bales was slightly lower than that of a.m. bales (Figure 1b), although it is important to note that the omasal collection was done from d 15 to 17. Overall, the mean TNC concentration of p.m. alfalfa was greater $(P<$ 0.01 ) than that of a.m. alfalfa with a difference in TNC content that averaged $23 \mathrm{~g} / \mathrm{kg}$ of DM during the $10 \mathrm{~d}$ of data and sample collection over both periods (Table $1)$.

Intakes of $\mathrm{DM}(P=0.01)$ and $\mathrm{OM}(P<0.01)$ during the 10-d collection period were both greater when feeding p.m. rather than a.m. alfalfa (Table 3). Yields of milk and milk components were also significantly greater when cows were fed p.m.- vs. a.m.-cut alfalfa baleage, indicating that enhanced feed intake increased milk production. Digestible OM intake was $0.8 \mathrm{~kg} / \mathrm{d}$ greater when feeding p.m.- than a.m.-cut alfalfa (Table 4), which corresponds to an increment of $13 \mathrm{MJ}$ of ME intake with the former treatment assuming an energy content of $16 \mathrm{MJ} / \mathrm{kg}$ of digestible OM (Ministry of Ag- 
(a)

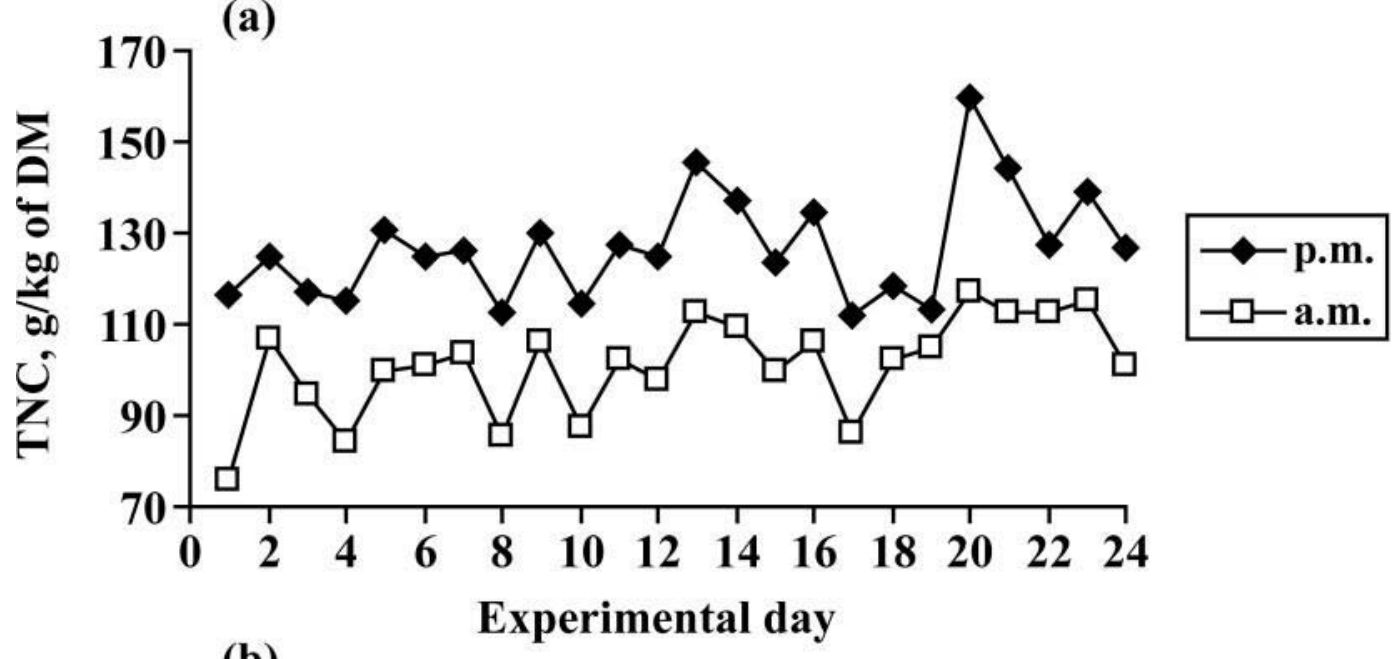

(b)

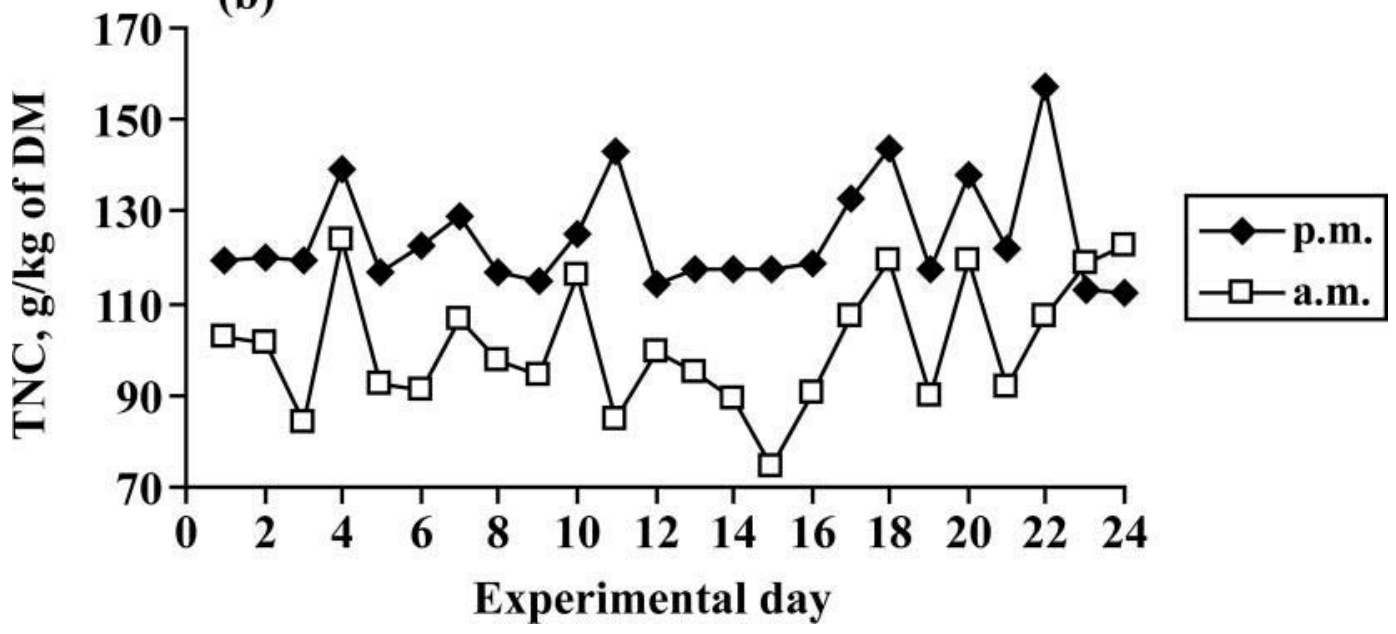

Figure 1. Daily concentration of total nonstructural carbohydrates (TNC) of each pair of bales (p.m. and a.m.) fed to late-lactation cows during period 1 (a) and period 2 (b).

riculture, Fisheries and Food, 1984). Considering that cows fed p.m. alfalfa yielded $1.6 \mathrm{~kg} / \mathrm{d}$ more ECM $(P=$ 0.02 ) than those fed a.m. alfalfa (Table 3 ), the marginal response in ECM to incremental ME intake was 0.12 $\mathrm{kg}$ of $\mathrm{ECM} / \mathrm{MJ}$ of ME, which is in agreement with literature data (Huhtanen, 1998). Therefore, the observed increase in milk yield with feeding p.m. alfalfa can be attributed to the greater intakes of DM, OM, and ME. Both MUN $(P<0.01)$ and plasma urea N $(P=0.03)$ were lower with feeding p.m.- vs. a.m.-cut alfalfa baleage, suggesting improvement in $\mathrm{N}$ utilization by shifting alfalfa cutting from sunup to sundown (Table 3 ). However, urea $\mathrm{N}$ data should be interpreted cautiously because the concentration of $\mathrm{CP}$ in p.m. alfalfa was $10 \mathrm{~g} / \mathrm{kg}$ of DM lower than that of a.m. alfalfa (Table 2). According to Nousiainen et al. (2004), dietary CP concentration was the best single predictor of MUN in cows fed grass silage-based diets, indicating that MUN increased $1.7 \mathrm{mg} / \mathrm{dL}$ per percentage unit increase in dietary $\mathrm{CP}$ content.

\section{Intake, Digestibility, and Omasal Flow of Nutrients}

Intake $(P<0.09)$ and omasal flow of DM $(P<0.06)$ tended to be greater when feeding p.m. instead of a.m. baleage to late-lactation dairy cows (Table 4); apparent ruminal DM digestibility of p.m. and a.m. alfalfa did not differ significantly and averaged $6.31 \mathrm{~kg} / \mathrm{d}$ or $32.5 \%$ of DMI. However, DM apparently digested in the intestines $(P=0.08 ;+0.73 \mathrm{~kg} / \mathrm{d})$ and in the total tract $(P=0.04 ;+0.90 \mathrm{~kg} / \mathrm{d})$ was greater when cows were fed p.m. vs. a.m. alfalfa baleage (Table 4). It is important to note that about half of the total-tract DM digestion occurred postruminally across forage treatments, which appears unrealistic for animals fed alfalfa as the sole dietary ingredient. Ash concentration of OTD samples 
Table 3. Intake and milk yield and composition in dairy cows fed baleages harvested from alfalfa cut at sundown (p.m.) or sunup (a.m.)

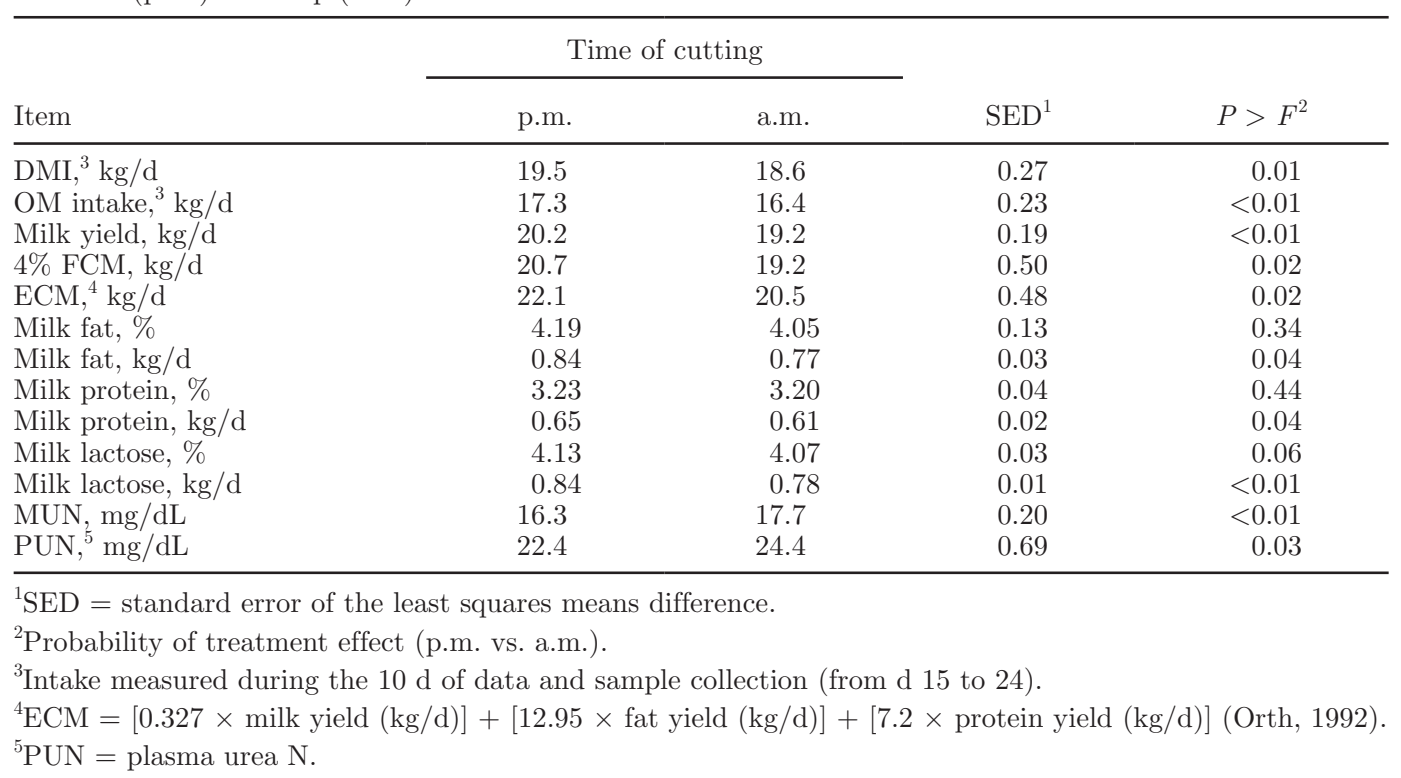

averaged 28\% (data not shown) in the current study and probably contributed to the abnormally low ruminal digestibility of DM. It is not uncommon to find such high concentrations of ash in OTD samples. In fact, calculated OTD ash concentrations averaged 17, 18 , and $23 \%$ among treatments in the studies of Brito et al. (2006, 2007a,b), respectively. These high concentrations of ash in OTD samples across different studies can be explained not only by minerals present in the feed, premixes, and soil ingested by the animals but also by minerals contained in the saliva. According to Tuori et al. (2006), the mean omasal flow of $\mathrm{Na}(1,024 \mathrm{~g} / \mathrm{d})$ is 25-fold greater than the mean $\mathrm{Na}$ intake $(41 \mathrm{~g} / \mathrm{d})$, whereas the mean omasal flow of $\mathrm{P}(169 \mathrm{~g} / \mathrm{d})$ is 2 -fold greater than the mean $\mathrm{P}$ intake $(79 \mathrm{~g} / \mathrm{d})$, indicating a net salivary secretion of these 2 macrominerals into the rumen. In addition, Punia et al. (1988) reported a net salivary secretion of minerals into the rumen that averaged $599 \mathrm{~g} / \mathrm{d}$ across treatments. Because the omasum is considered as a major site of minerals absorption (Edrise et al., 1986; Punia et al., 1988; Ahvenjärvi et al., 2000; Tuori et al., 2006), comparisons between omasal and duodenal DM flows should be done carefully. Therefore, the high concentration of ash present in the omasal digesta may result in an estimate of DM flow that is greater when samples are collected in the omasal canal than in the proximal duodenum. Punia et al. (1988) demonstrated that the mean omasal flow of DM was $353 \mathrm{~g} / \mathrm{d}$ greater than the mean duodenal flow of DM leading to estimates of ruminal DM digestibilities of 25 and $33 \%$ of DMI when using omasal vs. duodenal digesta flows in the computations, respectively. Therefore, the extent of DM digestion in the rumen is certainly affected by the amount of inorganic matter present in the digesta, offering an explanation for low values of ruminal DM digestibility mainly when omasal digesta is collected.

Intake $(P=0.07)$ and omasal flow of OM $(P=0.08)$ tended to be greater when feeding p.m.- rather than a.m.-cut alfalfa baleage to late-lactation dairy cows (Table 4). Organic matter apparently digested in the rumen and postrumen, and truly digested in the rumen, did not differ between forage treatments, which agrees with Lee et al. (2002), who fed high- vs. lowWSC perennial ryegrass to steers. However, apparent total-tract digestibility of $\mathrm{OM}$ was $0.8 \mathrm{~kg} / \mathrm{d}$ greater $(P$ $=0.04$ ) with feeding p.m. instead of a.m. alfalfa. Therefore, increased milk production of late-lactation cows fed p.m. alfalfa (Table 3) could be explained by the enhanced intakes (Tables 3 and 4), omasal flows (Table 4), and total-tract digestibilities (Table 4) of DM and OM . Intakes, omasal flows, and apparent digestibilities of NDF (Table 4) and ADF (data not shown) in the rumen and postrumen did not differ when cows were fed p.m. or a.m. alfalfa baleage. According to Titgemeyer (1997), partition of fiber digestion between ruminal and postruminal compartments can be used as an indicator of marker dysfunction because if duodenal digesta flow is overestimated, ruminal fiber digestion is proportionally underestimated, erroneously indicating that a large portion of fiber is digested in the intestines. Thus, for ruminants fed forage-based diets, ruminal fiber digestion typically is about equal to total-tract fiber digestibility (Titgemeyer, 1997). In fact, we observed that NDF apparently digested in the rumen and in the total tract averaged, respectively, 44 and $48 \%$ of NDF intake 
Table 4. Intake, omasal flow, and digestibility of nutrients in dairy cows fed baleages harvested from alfalfa cut at sundown (p.m.) or sunup (a.m.)

\begin{tabular}{|c|c|c|c|c|}
\hline \multirow[b]{2}{*}{ Item } & \multicolumn{2}{|c|}{ Time of cutting } & \multirow[b]{2}{*}{$\mathrm{SED}^{1}$} & \multirow[b]{2}{*}{$P>F^{2}$} \\
\hline & p.m. & a.m. & & \\
\hline \multicolumn{5}{|l|}{$\mathrm{DM}$} \\
\hline Intake, ${ }^{3} \mathrm{~kg} / \mathrm{d}$ & 19.8 & 18.9 & 0.43 & 0.09 \\
\hline Omasal flow, $\mathrm{kg} / \mathrm{d}$ & 13.4 & 12.7 & 0.29 & 0.06 \\
\hline \multicolumn{5}{|c|}{ Apparently digested in the rumen } \\
\hline $\mathrm{kg} / \mathrm{d}$ & 6.41 & 6.21 & 0.33 & 0.57 \\
\hline$\%$ of DMI & 32.3 & 32.7 & 1.40 & 0.80 \\
\hline \multicolumn{5}{|c|}{ Apparently digested postruminally } \\
\hline $\mathrm{kg} / \mathrm{d}$ & 6.62 & 5.89 & 0.34 & 0.08 \\
\hline$\%$ of DMI & 33.4 & 31.3 & 1.81 & 0.28 \\
\hline$\%$ of passage to omasum & 49.2 & 46.3 & 1.88 & 0.17 \\
\hline \multicolumn{5}{|c|}{ Apparently digested in the total tract } \\
\hline $\mathrm{kg} / \mathrm{d}$ & 13.0 & 12.1 & 0.36 & 0.04 \\
\hline$\%$ of DMI & 65.7 & 63.9 & 0.99 & 0.12 \\
\hline \multicolumn{5}{|l|}{$\mathrm{OM}$} \\
\hline Intake, $\mathrm{kg} / \mathrm{d}$ & 17.5 & 16.7 & 0.38 & 0.07 \\
\hline Omasal flow, $\mathrm{kg} / \mathrm{d}$ & 9.61 & 9.19 & 0.20 & 0.08 \\
\hline \multicolumn{5}{|c|}{ Apparently digested in the rumen } \\
\hline $\mathrm{kg} / \mathrm{d}$ & 7.94 & 7.55 & 0.35 & 0.30 \\
\hline$\%$ of OM intake & 45.1 & 44.9 & 1.31 & 0.91 \\
\hline \multicolumn{5}{|l|}{ Truly digested in the rumen } \\
\hline $\mathrm{kg} / \mathrm{d}$ & 11.8 & 11.1 & 0.36 & 0.12 \\
\hline$\%$ of OM intake & 67.1 & 66.5 & 0.98 & 0.56 \\
\hline \multicolumn{5}{|c|}{ Apparently digested postruminally } \\
\hline $\mathrm{kg} / \mathrm{d}$ & 3.70 & 3.24 & 0.25 & 0.12 \\
\hline$\% \mathrm{OM}$ intake & 21.0 & 19.5 & 1.53 & 0.37 \\
\hline$\%$ of passage to omasum & 38.3 & 35.2 & 2.15 & 0.21 \\
\hline \multicolumn{5}{|c|}{ Apparently digested in the total tract } \\
\hline $\mathrm{kg} / \mathrm{d}$ & 11.6 & 10.8 & 0.32 & 0.04 \\
\hline$\%$ of OM intake & 66.1 & 64.4 & 1.00 & 0.16 \\
\hline \multicolumn{5}{|l|}{ NDF } \\
\hline Intake, $\mathrm{kg} / \mathrm{d}$ & 7.61 & 7.49 & 0.23 & 0.62 \\
\hline Omasal flow, $\mathrm{kg} / \mathrm{d}$ & 4.33 & 4.09 & 0.21 & 0.29 \\
\hline \multicolumn{5}{|c|}{ Apparently digested in the rumen } \\
\hline $\mathrm{kg} / \mathrm{d}$ & 3.27 & 3.40 & 0.38 & 0.75 \\
\hline$\%$ of NDF intake & 42.7 & 45.0 & 3.30 & 0.52 \\
\hline \multicolumn{5}{|c|}{ Apparently digested postruminally } \\
\hline $\mathrm{kg} / \mathrm{d}$ & 0.47 & 0.09 & 0.25 & 0.18 \\
\hline$\%$ of NDF intake & 6.35 & 1.20 & 3.59 & 0.20 \\
\hline$\%$ of passage to omasum & 10.1 & 1.47 & 6.49 & 0.23 \\
\hline \multicolumn{5}{|c|}{ Apparently digested in the total tract } \\
\hline $\mathrm{kg} / \mathrm{d}$ & 3.74 & 3.49 & 0.21 & 0.28 \\
\hline$\%$ of NDF intake & 49.1 & 46.2 & 1.76 & 0.15 \\
\hline
\end{tabular}

across forage treatments (Table 4), showing that $92 \%$ of the total digestibility of NDF took place in the rumen, which agrees with Titgemeyer (1997), who stated that for ruminants fed high-quality forage more than $80 \%$ of the total fiber ingested by the animal is digested in the rumen. Moreover, only a small amount of NDF was apparently digested postruminally, which is expected for cows fed forage as the sole dietary ingredient. Yet according to Titgemeyer (1997), true ruminal OM digestion of forage-based diets is approximately equal to total-tract OM digestion, which is corroborated by data (Table 4) from the current study, further indicat- ing that our marker methodology accurately estimated digesta flow of nutrients. It is also important to note that $69 \%$ of the total apparent OM digestion occurred in the rumen across treatments (Table 4), thus suggesting that the partition of $\mathrm{OM}$ digestibility in the gastrointestinal tract was as expected.

\section{Intake, Digestibility, and Omasal Flow of $\mathrm{N}$}

Intake of $\mathrm{N}$ with feeding p.m. or a.m. alfalfa did not differ and averaged $567 \mathrm{~g} / \mathrm{d}$ (Table 5). Similarly, N apparently digested in the rumen and postruminally did 
not differ across forage treatments (Table 5). However, $\mathrm{N}$ truly digested in the rumen, expressed as a proportion of $\mathrm{N}$ intake, was greater $(P<0.01$; Table 5$)$ when cows were fed p.m. (79\%) vs. a.m. alfalfa $(74 \%)$, thus suggesting that longer wilting time of alfalfa cut at sundown increased forage proteolysis as will be discussed later. Apparent ruminal digestibility of $\mathrm{N}$ did not differ between steers fed high- vs. low-WSC ryegrass (Lee et al., 2002) or among steers fed silages harvested from high- or low-WSC ryegrass or 50:50 mixtures of ryegrass and red clover (Trifolium pratense; Merry et al., 2006). Hristov and Ropp (2003) observed that $\mathrm{N}$ truly digested in the rumen was not affected when late-lactation cows were fed alfalfa-based diets formulated to contain either a greater concentration of ruminally fermentable TNC or ruminally fermentable fiber. In a subsequent trial, Hristov et al. (2005) reported no change in true ruminal $\mathrm{N}$ digestibility with late-lactation cows fed a basal alfalfa hay diet supplemented intraruminally with white oat fiber, corn dextrose, corn starch, or a mix containing apple pectin plus these other 3 carbohydrate sources in equal proportions. Therefore, ruminal $\mathrm{N}$ digestibility appears not to be affected when the availability of ruminally fermentable energy is increased with feeding different carbohydrate supplements.

Omasal flow of total $\mathrm{N}$ expressed as grams per day $(P=0.57)$ or as a proportion of $\mathrm{N}$ intake $(P=0.78)$ did not differ when cows were fed p.m. or a.m. alfalfa baleage (Table 5). The lack of a significant difference in the passage of total $\mathrm{N}$ to the small intestine is not surprising considering that $\mathrm{N}$ intake was only $14 \mathrm{~g} / \mathrm{d}$ greater $(P=0.30)$ when feeding a.m.- rather than p.m.cut alfalfa. Ammonia $\mathrm{N}$ entering the omasal canal was similar between forage treatments (Table 5). Therefore, omasal flow of total NAN, expressed either as grams per day or as a proportion of $\mathrm{N}$ intake, was not affected by cutting time, averaging $448 \mathrm{~g} / \mathrm{d}$ and $79 \%$ across treatments, respectively (Table 5). Omasal flow of total bacterial NAN (FAB NAN plus PAB NAN) increased $(P<0.01)$ by $7 \%$ when cows were fed p.m. vs. a.m. alfalfa, whereas that of FAB NAN did not differ $(P$ $=0.20)$ across forage treatments (Table 5). However, omasal flow of PAB NAN was $16 \mathrm{~g} / \mathrm{d}$ greater $(P=$ 0.01 ) when late-lactation cows were fed p.m.- vs. a.m.cut alfalfa baleage. On average, 34 and $66 \%$ of the total bacterial NAN flow was derived from $\mathrm{FAB}$ and $\mathrm{PAB}$ NAN, respectively, in agreement with previous reports (Brito et al., 2006, 2007a,b).

Greater intakes of DM and OM (Tables 3 and 4) when feeding alfalfa cut at sundown (p.m.) might explain the observed increase in the omasal flow of total bacterial NAN (Table 5) considering that OMTDR (Table 4) did not differ between forage treatments. In fact, Clark et al. (1992) reported a positive relationship $\left(\mathrm{r}^{2}=0.62\right)$ between $\mathrm{OM}$ intake and passage of bacterial $\mathrm{N}$ to the small intestine in dairy cows. In addition, Oldick et al. (1999) showed that regression equations containing the independent variables DMI and dietary concentration of NDF were the best predictors of duodenal flow of bacterial $\mathrm{N}$ when a data set including 213 treatments means from 55 published studies was used in the analyses. Trevaskis et al. (2001) reported that sheep fed p.m. biennial ryegrass (Lolium multiflorum) ingested $25 \%$ more pasture DM (252 vs. $201 \mathrm{~g} / \mathrm{d}$ ) and excreted more allantoin in their urine than those fed a.m.-cut ryegrass, suggesting an improvement in microbial protein synthesis. However, when these same authors fed p.m.- vs. a.m.-cut kikuyu grass (Pennisetum clandestinum) with DMI adjusted for a daily ingestion rate of $400 \mathrm{~g}$ across treatments, sheep receiving p.m. kikuyu also excreted more urinary allantoin, indicating, at least in this case, that the significant increase in microbial protein synthesis was not due to an increase in feed intake.

Experiments with growing beef steers fed high- vs. low-WSC ryegrass also demonstrated that bacterial protein synthesis was significantly increased by 27 (Lee et al., 2002) to $52 \%$ (Merry et al., 2006). In both studies, intakes of DM and OM were significantly increased when feeding high- vs. low-WSC ryegrass varieties, showing that enhanced energy intake was the main driving force to the reported increases in the duodenal flow of bacterial $\mathrm{N}$ in both trials. Moorby et al. (2006) using early lactation dairy cows observed that the urinary excretion of purine derivatives tended $(P=0.06)$ to increase $(+61 \%)$, whereas DMI was significantly increased $(+2.8 \mathrm{~kg} / \mathrm{d})$ when animals were fed high- vs. low-WSC ryegrass, further indicating the positive relationship between intake and microbial protein synthesis. Jaakkola et al. (2006) observed a linear increase in the duodenal flow of bacterial $\mathrm{N}$ when both the application rate of formic acid and the concentration of WSC enhanced from 0 to $6 \mathrm{~L} / \mathrm{t}$ and from 3 to $92 \mathrm{~g} / \mathrm{kg}$ of DM in grass silage fed to young bulls. However, OM intake was not affected by the increasing concentrations of formic acid and WSC, thus suggesting that the observed enhanced duodenal flow of bacterial $\mathrm{N}$ was due to differences in energy or protein-yielding substrates or both according to the authors.

Because the effect of high-sugar forages on ruminal outflow of bacterial $\mathrm{N}$ appears to be confounded with intakes of $\mathrm{DM}$ and $\mathrm{OM}$, the role of $\mathrm{TNC}$ on forage preference should not be neglected. Fisher et al. (1999, 2002) identified TNC, or at least one of its constituents, as an important contributor to ruminant's preference when tall fescue or alfalfa hay mowing was shifted from sunup to sundown. In addition, Orr et al. (1997) investigating the effects of time of day on the ingestive behavior of sheep grazing ryegrass or white clover (Tri- 
Table 5. Intake, digestibility, and omasal flow of $\mathrm{N}$ constituents in dairy cows fed baleages harvested from alfalfa cut at sundown (p.m.) or sunup (a.m.)

\begin{tabular}{|c|c|c|c|c|}
\hline \multirow[b]{2}{*}{ Item } & \multicolumn{2}{|c|}{ Time of cutting } & \multirow[b]{2}{*}{$\mathrm{SED}^{1}$} & \multirow[b]{2}{*}{$P>F^{2}$} \\
\hline & p.m. & a.m. & & \\
\hline $\mathrm{N}$ intake, $\mathrm{g} / \mathrm{d}$ & 560 & 574 & 12.2 & 0.30 \\
\hline \multicolumn{5}{|l|}{$\mathrm{N}$ apparently digested in the rumen } \\
\hline $\mathrm{g} / \mathrm{d}$ & 110 & 116 & 11.2 & 0.61 \\
\hline$\%$ of $\mathrm{N}$ intake & 19.4 & 20.0 & 2.01 & 0.78 \\
\hline \multicolumn{5}{|l|}{$\mathrm{N}$ truly digested in the rumen } \\
\hline $\mathrm{g} / \mathrm{d}$ & 442 & 427 & 9.35 & 0.15 \\
\hline$\%$ of $\mathrm{N}$ intake & 78.8 & 74.4 & 0.98 & $<0.01$ \\
\hline \multicolumn{5}{|l|}{$\mathrm{N}$ apparently digested postruminally } \\
\hline $\mathrm{g} / \mathrm{d}$ & 287 & 297 & 12.3 & 0.47 \\
\hline$\%$ of $\mathrm{N}$ intake & 51.2 & 52.0 & 2.23 & 0.74 \\
\hline$\%$ of passage to omasum & 63.5 & 64.8 & 1.18 & 0.31 \\
\hline \multicolumn{5}{|l|}{$\mathrm{N}$ apparently digested in the total tract } \\
\hline $\mathrm{g} / \mathrm{d}$ & 397 & 413 & 11.2 & 0.20 \\
\hline$\%$ of $\mathrm{N}$ intake & 70.7 & 71.2 & 0.93 & 0.22 \\
\hline \multicolumn{5}{|l|}{ Flow at omasal canal } \\
\hline $\mathrm{N}, \mathrm{g} / \mathrm{d}$ & 451 & 458 & 12.4 & 0.57 \\
\hline $\mathrm{N}, \%$ of $\mathrm{N}$ intake & 80.6 & 80.0 & 2.01 & 0.78 \\
\hline $\mathrm{NH}_{3}-\mathrm{N}, \mathrm{g} / \mathrm{d}$ & 6.47 & 6.05 & 0.58 & 0.49 \\
\hline NAN, g/d & 444 & 452 & 12.7 & 0.56 \\
\hline NAN, $\%$ of $N$ intake & 79.4 & 79.0 & 2.08 & 0.83 \\
\hline \multicolumn{5}{|l|}{ FAB $^{3}$ NAN } \\
\hline $\mathrm{g} / \mathrm{d}$ & 110 & 105 & 3.81 & 0.20 \\
\hline$\%$ of total bacterial NAN & 33.4 & 33.7 & 1.06 & 0.80 \\
\hline \multicolumn{5}{|l|}{$\mathrm{PAB}^{4}$ NAN } \\
\hline $\mathrm{g} / \mathrm{d}$ & 222 & 206 & 4.61 & 0.01 \\
\hline$\%$ of total bacterial NAN & 66.6 & 66.4 & 1.06 & 0.80 \\
\hline \multicolumn{5}{|l|}{ Total bacterial NAN } \\
\hline $\mathrm{g} / \mathrm{d}$ & 332 & 311 & 4.84 & $<0.01$ \\
\hline$\%$ of NAN & 74.7 & 68.9 & 1.07 & $<0.01$ \\
\hline $\mathrm{NANBN}^{5} \mathrm{~g} / \mathrm{d}$ & 112 & 141 & 8.67 & 0.02 \\
\hline NANBN, $\%$ of NAN flow & 25.3 & 31.1 & 1.07 & $<0.01$ \\
\hline NANBN, $\%$ of $\mathrm{N}$ intake & 20.1 & 24.6 & 1.03 & $<0.01$ \\
\hline NANBN, $\%$ of DMI & 0.57 & 0.75 & 0.03 & $<0.01$ \\
\hline \multicolumn{5}{|l|}{ RDP supply } \\
\hline $\mathrm{g} / \mathrm{d}$ & 2763 & 2668 & 57.7 & 0.15 \\
\hline$\%$ of DMI & 14.0 & 14.1 & 0.19 & 0.49 \\
\hline \multicolumn{5}{|l|}{ EBPS $^{6}$} \\
\hline $\mathrm{g}$ of total bacterial NAN $/ \mathrm{kg}$ of $\mathrm{OMADR}^{7}$ & 42.2 & 41.8 & 2.15 & 0.86 \\
\hline $\mathrm{g}$ of total bacterial NAN $/ \mathrm{kg}$ of $\mathrm{OMTDR}^{8}$ & 28.3 & 28.1 & 0.99 & 0.86 \\
\hline \multicolumn{5}{|l|}{$\mathrm{ENU}^{9}$} \\
\hline $\mathrm{g}$ of total bacterial NAN/g of $\mathrm{N}$ intake & 0.60 & 0.54 & 0.01 & $<0.01$ \\
\hline $\mathrm{g}$ of total bacterial NAN/g of rumen-degradable $\mathrm{N}^{10}$ & 0.75 & 0.73 & 0.02 & 0.45 \\
\hline \multicolumn{5}{|l|}{${ }^{1} \mathrm{SED}=$ standard error of the least squares means difference. } \\
\hline \multicolumn{5}{|l|}{${ }^{2}$ Probability of treatment effect (p.m. vs. a.m.). } \\
\hline \multicolumn{5}{|l|}{${ }^{3} \mathrm{FAB}=$ fluid-associated bacteria. } \\
\hline \multicolumn{5}{|l|}{${ }^{4} \mathrm{PAB}=$ particle-associated bacteria. } \\
\hline \multicolumn{5}{|l|}{${ }^{5} \mathrm{NANBN}=$ non- $\mathrm{NH}_{3}$ nonbacterial $\mathrm{N}$. } \\
\hline${ }^{6} \mathrm{EBPS}=$ efficiency of bacterial protein synthesis. & & & & \\
\hline${ }^{7} \mathrm{OMADR}=\mathrm{OM}$ apparently digested in the rumen. & & & & \\
\hline${ }^{8} \mathrm{OMTDR}=\mathrm{OM}$ truly digested in the rumen. & & & & \\
\hline${ }^{9} \mathrm{ENU}=$ efficiency of $\mathrm{N}$ use. & & & & \\
\hline${ }^{10}$ Rumen-degradable $\mathrm{N}=\mathrm{RDP} \div 6.25$. & & & & \\
\hline
\end{tabular}

folium repens) demonstrated that the linear increases in mastication rate (chews/min; $P=0.01$ ), bite mass ( $\mathrm{mg}$ of $\mathrm{DM} /$ bite; $P=0.02)$, and intake rate $(\mathrm{g}$ of $\mathrm{DM} / \mathrm{min}$; $P=0.057$ ) between 0730 to $1930 \mathrm{~h}$ coincided with the linear increases in the concentrations of forage WSC and starch during this same time period. When these same group of researchers (Orr et al., 2001) allocated lactating dairy cows to new areas of grass in strip grazing after the morning (a.m.) or afternoon (p.m.) milkings, they observed that animals offered p.m. pasture had a longer meal $(>4 \mathrm{~h})$ than those receiving a.m. pasture $(2$ to $3 \mathrm{~h}$ ), which also spent more time ruminating (a.m.: 
Table 6. Composition and isotopic enrichment of ruminal bacteria in dairy cows fed baleages harvested from alfalfa cut at sundown (p.m.) or sunup (a.m.)

\begin{tabular}{|c|c|c|c|c|}
\hline \multirow[b]{2}{*}{ Item } & \multicolumn{2}{|c|}{ Time of cutting } & \multirow[b]{2}{*}{$\mathrm{SED}^{1}$} & \multirow[b]{2}{*}{$P>F^{2}$} \\
\hline & p.m. & a.m. & & \\
\hline $\begin{array}{l}{ }^{15} \mathrm{NH}_{3} \mathrm{APE}^{3} \\
\mathrm{FAB}^{4}\end{array}$ & 0.0799 & 0.0884 & 0.0023 & 0.01 \\
\hline OM, $\%$ of $\mathrm{DM}$ & 73.5 & 74.2 & 0.69 & 0.37 \\
\hline NAN, $\%$ of DM & 6.97 & 6.94 & 0.08 & 0.66 \\
\hline${ }^{15} \mathrm{~N}$ APE & 0.0503 & 0.0503 & 0.0017 & 0.99 \\
\hline${ }^{15} \mathrm{~N}$ from ${ }^{15} \mathrm{NH}_{3} \mathrm{APE},{ }^{5} \%$ & 62.9 & 57.0 & 1.57 & $<0.01$ \\
\hline \multicolumn{5}{|l|}{$\mathrm{PAB}^{6}$} \\
\hline $\mathrm{OM}, \%$ of $\mathrm{DM}$ & 76.9 & 77.5 & 0.72 & 0.46 \\
\hline NAN, $\%$ of DM & 6.34 & 6.46 & 0.11 & 0.32 \\
\hline${ }^{15} \mathrm{~N}$ APE & 0.0438 & 0.0435 & 0.0011 & 0.84 \\
\hline${ }^{15} \mathrm{~N}$ from ${ }^{15} \mathrm{NH}_{3}$ APE, $\%$ & 54.8 & 49.4 & 1.47 & 0.01 \\
\hline $\begin{array}{l}\text { Total bacteria } \\
{ }^{15} \mathrm{~N} \text { from }{ }^{15} \mathrm{NH}_{3} \text { APE },{ }^{7} \%\end{array}$ & 57.6 & 52.1 & 1.46 & $<0.01$ \\
\hline $\begin{array}{l}{ }^{1} \mathrm{SED}=\text { standard error of } \\
{ }^{2} \mathrm{Probability} \text { of treatment } \mathrm{e} \\
{ }^{3} \mathrm{APE}=\text { atom percent exce } \\
{ }^{4} \mathrm{FAB}=\text { fluid-associated ba } \\
{ }^{5}\left({ }^{15} \mathrm{~N} \text { APE in FAB or PAB }\right. \\
{ }^{6} \mathrm{PAB}=\text { particle-associated } \\
{ }^{7}\left[\left({ }^{15} \mathrm{~N} \text { APE in FAB } \times \% \text { of }\right.\right. \\
\text { rial NAN flow })] \div{ }^{15} \mathrm{NH}_{3} \mathrm{~A}\end{array}$ & $\begin{array}{l}\text { eans diffe } \\
\text {.). }\end{array}$ & AF & $\times \%$ & \\
\hline
\end{tabular}

454 vs. p.m.: $433 \mathrm{~min} / \mathrm{d})$. Because the greater concentration of grass WSC in p.m. (204 g/ $\mathrm{kg}$ of DM) vs. a.m. pasture $(175 \mathrm{~g} / \mathrm{kg}$ of $\mathrm{DM})$ coincided with a longer evening meal, it can be hypothesized that enhanced herbage WSC improved grass palatability, which agrees with Provenza et al. (1998). Hence, the positive effect of TNC on palatability may explain the increased DMI with feeding p.m.- vs. a.m.-cut alfalfa baleage to latelactation dairy cows reported earlier (Brito et al., 2008) and presently.

However, increased forage TNC would also be expected to improve the capacity of ruminal microbes to capture $\mathrm{NH}_{3}$ and use it as an $\mathrm{N}$ source for growth and yield (Rook et al., 1987). Ammonia is often the main $\mathrm{N}$ source for microbial protein synthesis (Nolan, 1975; Aharoni et al., 1991), and it is essential for the growth of several species of ruminal bacteria (Blackburn, 1965; Allison, 1970; Bryant, 1973). In fact, ruminal bacteria (FAB: $P<0.01$; PAB: $P=0.01$; and total bacteria: $P$ $<0.01$ ) incorporated more $\mathrm{NH}_{3}-\mathrm{N}$ when cows were fed p.m. vs. a.m. alfalfa (Table 6), further explaining the enhanced omasal flow of bacterial NAN with sundowncut forage (Table 5).

The omasal flow of NANBN was $29 \mathrm{~g} / \mathrm{d}$ lower $(P=$ 0.02; Table 5) when cows were fed p.m. vs. a.m. alfalfa, suggesting greater ruminal degradation of protein from p.m. alfalfa compared with protein from a.m. alfalfa. Increased proteolysis during field-wilting may offer an explanation for the decreased omasal flow of NANBN when feeding p.m.-cut alfalfa baleage. Brady (1960) demonstrated that increasing wilting time from 0 to $26.5 \mathrm{~h}$ also enhanced NPN formation from 89 to 173 $\mathrm{g} / \mathrm{kg}$ of total $\mathrm{N}$ in ryegrass. Similarly, Harrison et al. (2003) observed a positive relationship between NPN formation and wilting time using a regression approach. Although in the current trial DM concentration was only $13 \mathrm{~g} / \mathrm{kg}$ greater in p.m. than in a.m. alfalfa (Table 1 ), the former was approximately $18 \mathrm{~h}$ more fieldwilted when compared with the latter, which may have increased proteolysis. In fact, we observed that NPN concentration expressed as a proportion of total $\mathrm{CP}$ was numerically greater in p.m.-cut $(50.3 \%)$ than in a.m.-cut alfalfa baleage $(47.1 \%)$, thus indicating more proteolysis with the former forage.

Efficiency of bacterial protein synthesis (EBPS; Table 5), expressed either as grams of bacterial NAN per kilogram of OM apparently digested in the rumen (OMADR) or as grams of bacterial NAN per kilogram of OMTDR, did not differ significantly between forage treatments, which agrees with data from Peyraud et al. (1997). Similarly, Lee et al. (2002), feeding highvs. low-WSC ryegrass to steers, found no difference in EBPS when expressed as grams of bacterial $\mathrm{N}$ per kilogram of OMADR. Based on dietary N concentrations of 16.6 and $15.9 \mathrm{~g}$ of $\mathrm{N} / \mathrm{kg}$ of DM for the high- and low-WSC diets and low ruminal $\mathrm{NH}_{3}$ concentration $(<5$ $\mathrm{mg} / \mathrm{dL}$ ), it can be concluded that poor $\mathrm{N}$ supply may have prevented an improvement in EBPS with feeding the high-sugar diet in Lee et al. (2002) trial. In the current study, insufficient dietary $\mathrm{N}$ could not explain 
the lack of treatment effect on EBPS because dietary $\mathrm{N}$ concentration averaged $29.4 \mathrm{~g}$ of $\mathrm{N} / \mathrm{kg}$ of $\mathrm{DM}$, a value about 2-fold greater when compared with data from Lee et al. (2002). Although both OMADR and OMTDR did not differ significantly with feeding p.m. vs. a.m. alfalfa (Table 4), it appears that energy limited bacterial growth because only trace amounts of starch and TNC (data not shown) were found in a limited number of OTD samples across forage treatments. Carbohydrates contribute more than protein to OMADR and their fermentation also generates more ATP, thus increasing EBPS (Lee et al., 2002). Merry et al. (2006) reported that EBPS calculated based on OMADR or OMTDR was significantly greater in steers fed high-WSC grass silage than in those fed silages harvested from low-WSC grass and red clover, whereas the grass:red clover mixtures were greater than red clover silage alone. Despite forage being the sole dietary ingredient in the current trial and in that of Merry et al. (2006), EBPS did not differ in the former but did in the latter study possibly because the mean rumen-degradable $\mathrm{N}$ to WSC ratio was about 5 -fold greater in the present experiment.

Efficiency of $\mathrm{N}$ use (ENU), expressed in grams of bacterial NAN per gram of $\mathrm{N}$ intake, was greater $(P$ $<0.01$; Table 5) when cows were fed p.m. rather than a.m. baleage, which is in line with the significant increase in milk $\mathrm{N}$ efficiency previously reported (Brito et al., 2008). On the other hand, no difference was found when ENU was expressed as grams of bacterial NAN per gram of rumen-degradable $\mathrm{N}$ (Table 5). It is important to emphasize that along with the significant increase of $21 \mathrm{~g} / \mathrm{d}$ in bacterial NAN flow comparing p.m. vs. a.m. alfalfa, RDP supply also was numerically enhanced $(+95 \mathrm{~g} / \mathrm{d}$; Table 5$)$, which may have prevented ENU to differ significantly between treatments; in the computation of ENU as grams of bacterial NAN per gram of $\mathrm{N}$ intake, we observed a numerical reduction of $14 \mathrm{~g} / \mathrm{d}$ in $\mathrm{N}$ intake when cows were fed p.m. baleage (Table 5). Although ruminal $\mathrm{NH}_{3}$ concentrations were very high, it is worth mentioning that $\mathrm{N}$ recycled from urea and $\mathrm{NH}_{3}$ back to the rumen via saliva and rumen wall was not accounted for in the current computation of rumendegradable N. According to Kennedy and Milligan (1980), the clearance of plasma urea $\mathrm{N}$ to the rumen is inversely proportional to the concentration of ruminal $\mathrm{NH}_{3}$ in cattle and sheep, but it is increased when grain (starch) or sucrose is fed to the animal. Even though concentration of ruminal $\mathrm{NH}_{3}-\mathrm{N}$ was about the same between forage treatments (Brito et al., 2008), plasma urea $\mathrm{N}$ was decreased $(P=0.03$; Table 3$)$ and TNC concentration was increased $(P<0.01$; Table 1$)$ when feeding p.m. vs. a.m. alfalfa, suggesting more availability of ruminally fermentable energy.

\section{Intake and Omasal Flow of AA}

Intakes of all EAA except His and intakes of branchedchain AA and total EAA did not differ between forage treatments (Table 7$)$. Intake of His was decreased $(P$ $<0.01$ ) comparing p.m. vs. a.m. alfalfa because its concentration was $21 \%$ lower in alfalfa cut at sundown (Table 2). Intakes of all non-EAA (NEAA) except Glx (Glu plus Gln) and Pro and intakes of total NEAA and total AA did not differ when late-lactation dairy cows were fed p.m. rather than a.m. alfalfa (Table 7). Although the concentrations of $\mathrm{N}$ and $\mathrm{AA}$ were numerically lower in p.m. compared with a.m. baleage (Table 2), DMI was greater (Tables 3 and 4) when cows were fed p.m. alfalfa, resulting in few significant differences in AA intake across forage treatments.

Omasal flow of most EAA (Ile, Leu, Lys, Phe, and Thr: $P<0.05)$, branched-chain AA $(P=0.03)$, and total EAA $(P=0.03)$ of total bacterial origin increased when cows were fed p.m. instead of a.m. alfalfa (Table $7)$. With the exception of Pro, all remaining NEAA $(P$ $\leq 0.05)$, total NEAA $(P=0.03)$, and total AA $(P=$ 0.03 ) flows derived from total bacteria were increased when feeding p.m. vs. a.m. alfalfa baleage to dairy cows. Amino acids determined in the OTD samples were composed of bacterial protein, alfalfa protein escaping ruminal degradation, and, to a lesser extent, endogenous protein. The lack of significant effect of daytime cutting management on passage of OTD AA probably occurred because the greater $(P<0.01)$ bacterial NAN supply on p.m. alfalfa was counterbalanced by a greater $(P=0.02)$ NANBN supply on a.m. alfalfa (Table 5$)$. Lee et al. (2002) observed that the duodenal flow of 7 out of 9 EAA was significantly increased with feeding high- vs. low-WSC ryegrass to steers. However, total AA intake was $43 \%$ greater $(+203 \mathrm{~g} / \mathrm{d})$ when steers were fed high-WSC ryegrass and possibly contributed to the observed differences in duodenal flow of individual EAA. Peyraud et al. (1997) observed no differences in the AA composition of duodenal digesta feeding no(high WSC) vs. high-N fertilized ryegrass (low WSC) to lactating dairy cows except for the concentrations of His and Phe, which were decreased, and that of Met that tended to decrease in the former treatment. Intake of $\mathrm{N}$ was $28 \%$ lower $(-104 \mathrm{~g} / \mathrm{d})$ when cows were fed no-N fertilized grass, which may have been responsible for the differences in the duodenal concentration of some EAA in the study of Peyraud et al. (1997).

\section{CONCLUSIONS}

Enhancing TNC concentration of alfalfa by shifting forage cutting from sunup to sundown stimulated microbial protein synthesis and $\mathrm{NH}_{3}$ uptake by ruminal 
Table 7. Intake and omasal flow of amino acids $(\mathrm{g} / \mathrm{d})$ from total bacteria and omasal true digesta in dairy cows fed baleages harvested from alfalfa cut at sundown (p.m.) or sunup (a.m.)

\begin{tabular}{|c|c|c|c|c|c|c|c|c|c|c|c|c|}
\hline Item & \multicolumn{4}{|c|}{ Intake of AA } & \multicolumn{4}{|c|}{ Total bacterial AA } & \multicolumn{4}{|c|}{ Omasal true digesta AA } \\
\hline \multicolumn{13}{|c|}{ Essential AA } \\
\hline His & 39.4 & 47.3 & 0.94 & $<0.01$ & 23.8 & 22.8 & 0.61 & 0.15 & 35.6 & 37.9 & 1.54 & 0.19 \\
\hline Ile & 114 & 113 & 2.47 & 0.77 & 78.0 & 75.0 & 1.17 & 0.04 & 121 & 126 & 7.36 & 0.51 \\
\hline Met & 54.9 & 54.4 & 1.06 & 0.65 & 42.9 & 40.9 & 1.75 & 0.30 & 49.1 & 50.1 & 2.29 & 0.68 \\
\hline Phe & 130 & 131 & 2.90 & 0.77 & 84.3 & 79.1 & 1.31 & $<0.01$ & 127 & 132 & 5.88 & 0.46 \\
\hline Thr & 124 & 129 & 2.84 & 0.13 & 94.6 & 90.1 & 1.72 & 0.04 & 119 & 122 & 4.80 & 0.56 \\
\hline Val & 135 & 135 & 2.87 & 0.87 & 78.5 & 76.1 & 1.31 & 0.12 & 123 & 128 & 7.36 & 0.50 \\
\hline $\mathrm{BCAA}^{3}$ & 455 & 452 & 9.94 & 0.81 & 283 & 270 & 4.42 & 0.03 & 429 & 446 & 23.1 & 0.48 \\
\hline Total & 951 & 965 & 21.1 & 0.52 & 644 & 612 & 11.0 & 0.03 & 894 & 926 & 42.5 & 0.48 \\
\hline \multicolumn{13}{|c|}{ Nonessential AA } \\
\hline Tyr & 95.0 & 97.0 & 2.10 & 0.38 & 80.0 & 75.6 & 1.38 & 0.02 & 102 & 104 & 4.55 & 0.59 \\
\hline Total & 779 & 812 & 17.7 & 0.11 & 567 & 537 & 10.3 & 0.03 & 736 & 761 & 28.5 & 0.42 \\
\hline Total AA & 1,730 & 1,778 & 38.7 & 0.26 & 1,210 & 1,149 & 21.0 & 0.03 & 1,629 & 1,687 & 71.0 & 0.45 \\
\hline
\end{tabular}

${ }^{1} \mathrm{SED}=$ standard error of the least squares means difference.

${ }^{2}$ Probability of treatment effect (p.m. vs. a.m.).

${ }^{3} \mathrm{BCAA}=$ branched-chain $\mathrm{AA}(\mathrm{Ile}+\mathrm{Leu}+\mathrm{Val})$.

bacteria, thus suggesting that increased ruminally fermentable energy improved the capacity of microbes to capture $\mathrm{NH}_{3}$ and convert it into microbial protein. However, enhanced intake of DM and $\mathrm{OM}$ appears to be the main driving force to the observed increase in the omasal flow of bacterial NAN with feeding p.m.rather than a.m.-cut alfalfa baleage as the sole dietary ingredients to late-lactation dairy cows. Therefore, greater milk yield when cows were fed p.m. vs. a.m. alfalfa can be attributed to increased feed intake and apparent total-tract digestibilities of DM and $\mathrm{OM}$ with feeding the former treatment. Nitrogen truly digested in the rumen was significantly greater with feeding p.m. vs. a.m. alfalfa, indicating that longer wilting time of alfalfa cut at sundown increased forage proteolysis, which may also explain the decreased omasal flow of NANBN in cows fed p.m. alfalfa. No difference between forage treatments was found for the ruminal outflow of any AA of OTD origin, suggesting no positive effect of daytime cutting management on total AA passage to the small intestine.

\section{ACKNOWLEDGMENTS}

We thank Sylvie Provencher, Pamela Warburton, Véronique Roy, Jocelyne Renaud, and Frédéric Morel for sample collection and laboratory analyses at the
Dairy and Swine Research and Development Centre in Sherbrooke. The assistance of Mario Laterrière, Pierre Lechasseur, and Lucette Chouinard from the Soils and Crop Research and Development Center in Québec City for preparation and chemical analyses of forage used in this study is also acknowledged. The statistical advice of Steve Méthot (Dairy and Swine Research and Development Centre/Agriculture and Agri-Food Canada) and the critical manuscript review of Roger Martineau (Dairy and Swine Research and Development Centre/Agriculture and Agri-Food Canada) are gratefully acknowledged. The authors also thank Keith Carter and the barn crew for animal care and sampling at the Lennoxville Research Farm (Sherbrooke) and the Normandin Research Farm (Normandin) crew for cropping services. Appreciation is extended to $\mathrm{Ag}$ riculture and Agri-Food Canada and to La Fédération des Producteurs de Lait du Québec for their financial support.

\section{REFERENCES}

Aharoni, Y., H. Tagari, and R. C. Boston. 1991. A new approach to the quantitative estimation on nitrogen metabolic pathways in the rumen. Br. J. Nutr. 66:407-422.

Ahvenjärvi, S., A. Vanhatalo, P. Huhtanen, and T. Varvikko. 2000. Determination of reticulo-rumen and whole-stomach digestion in lactating cows by omasal canal or duodenal sampling. Br. J. Nutr. 83:67-77. 
Allison, M. J. 1970. Nitrogen metabolism of ruminal micro-organisms. Page 456-472 in Physiology of Digestion and Metabolism in the Ruminant. A. T. Phillipson, ed. Oriel Press, Newcastle-uponTyne, UK.

Berthiaume, R., C. Benchaar, A. V. Chaves, G. F. Tremblay, Y. Castonguay, A. Bertrand, G. Bélanger, R. Michaud, C. Lafrenière, and A. F. Brito. 2007. Increasing non structural carbohydrates in alfalfa improves in vitro microbial $\mathrm{N}$ synthesis. J. Dairy Sci. 90(Suppl. 1):430. (Abstr.)

Bertrand, A., D. Prévost, F. J. Bigras, and Y. Castonguay. 2007. Elevated atmospheric $\mathrm{CO}_{2}$ and strain of rhizobia alter cold tolerance and expression of COR genes in alfalfa (Medicago sativa L.). Ann. Bot. (Lond.) 99:275-284.

Blackburn, T. H. 1965. Nitrogen metabolism in the rumen. Page 322334 in Physiology of Digestion in the Ruminant. R. W. Dougherty, R. S. Allen, W. Burroughs, N. L. Jacobson, and A. D. McGilliard, ed. Oriel Press, Newcastle-upon-Tyne, UK.

Brady, C. J. 1960. Redistribution of nitrogen in grass and leguminous fodder plants during wilting and ensilage. J. Sci. Food Agric. $11: 276-284$.

Brito, A. F., G. A. Broderick, J. J. Olmos Colmenero, and S. M. Reynal. 2007a. Effects of feeding formate-treated alfalfa silage or red clover silage on omasal nutrient flow and microbial protein synthesis in lactating dairy cows. J. Dairy Sci. 90:1392-1404.

Brito, A. F., G. A. Broderick, and S. M. Reynal. 2006. Effects of varying dietary ratios of alfalfa silage to corn silage on omasal flow and microbial protein synthesis in dairy cows. J. Dairy Sci. 89:3939-3953.

Brito, A. F., G. A. Broderick, and S. M. Reynal. 2007b. Effects of different protein supplements on omasal nutrient flow and microbial protein synthesis in lactating dairy cows. J. Dairy Sci. 90:1828-1841.

Brito, A. F., G. F. Tremblay, A. Bertrand, Y. Castonguay, G. Bélanger, R. Michaud, H. Lapierre, C. Benchaar, H. V. Petit, D. Ouellet, and R. Berthiaume. 2008. Alfalfa cut at sundown improves milk yield of late-lactation dairy cows. J. Dairy Sci. 91:3968-3982.

Bryant, M. P. 1973. Nutritional requirements of the predominant rumen cellulolytic bacteria. Fed. Proc. 32:1809-1813.

Burns, J. C., D. S. Fisher, and H. F. Mayland. 2007. Diurnal shifts in nutritive value of alfalfa harvested as hay and evaluated by animal intake and digestion. Crop Sci. 47:2190-2197.

Burns, J. C., H. F. Mayland, and D. S. Fisher. 2005. Dry matter intake and digestion of alfalfa harvested at sunset and sunrise. J. Anim. Sci. 83:262-270.

Canadian Council on Animal Care. 1993. Guide to the Care and Use of Experimental Animals. Vol. 1. E. D. Offert, B. M. Cross, and A. A. McWilliam, ed. Canadian Council on Animal Care, Ottawa, Ontario.

Clark, J. H., T. H. Klusmeyer, and M. R. Cameron. 1992. Microbial protein synthesis and flows of nitrogen fractions to the duodenum of dairy cows. J. Dairy Sci. 75:2304-2323.

Cochran, R. C., D. C. Adams, J. D. Wallace, and M. L. Galyean. 1986. Predicting digestibility of different diets with internal markers: Evaluation of four potential markers. J. Anim. Sci. 63:14761487.

Edrise, B. M., R. H. Smith, and D. Hewitt. 1986. Exchanges of water and certain water-soluble minerals during passage of digesta through the stomach compartments of young ruminant bovines. Br. J. Nutr. 55:157-167.

Fisher, D. S., H. F. Mayland, and J. C. Burns. 1999. Variation in ruminant's preference for tall fescue hays cut either at sundown or at sunup. J. Anim. Sci. 77:762-768.

Fisher, D. S., H. F. Mayland, and J. C. Burns. 2002. Variation in ruminant preference for alfalfa hays cut at sunup and sundown. Crop Sci. 42:231-237.

France, J., and R. C. Siddons. 1986. Determination of digesta flow by continuous marker infusion. J. Theor. Biol. 121:105-120.

Harrison, J. H., P. Huhtanen, and M. Collins. 2003. Grass silage. Page 665-747 in Silage Science and Technology. D. R. Burton, J. H. Harrison, and R. E. Muck, ed. ASA, CSSA, SSSA, Madison, WI.
Hristov, A. N., and J. K. Ropp. 2003. Effect of dietary carbohydrate composition and availability on utilization of ruminal ammonia nitrogen for milk protein synthesis in dairy cows. J. Dairy Sci. 86:2416-2427.

Hristov, A. N., J. K. Ropp, K. L. Grandeen, S. Abedi, R. P. Etter, A. Melgar, and A. E. Foley. 2005. Effect of carbohydrate source on ammonia utilization in lactating dairy cows. J. Anim. Sci. 83:408-421.

Huhtanen, P. 1998. Supply of nutrients and productive responses in dairy cows given diets based on restrictively fermented silage. Agric. Food Sci. Finl. 7:219-250.

Huhtanen, P., P. G. Brotz, and L. D. Satter. 1997. Omasal sampling technique for assessing fermentative digestion in the forestomach of dairy cows. J. Anim. Sci. 75:1380-1392.

Huhtanen, P., K. Kaustell, and S. Jaakkola. 1994. The use of internal markers to predict total digestibility and duodenal flow of nutrients in cattle given six different diets. Anim. Feed Sci. Technol. 48:211-227.

Huntington, G. B., and J. C. Burns. 2007. Afternoon harvest increases readily fermentable carbohydrate concentration and voluntary intake of gamagrass and switchgrass baleage by beef steers. J. Anim. Sci. 85:276-284.

Jaakkola, S., V. Kaunisto, and P. Huhtanen. 2006. Volatile fatty acid proportions and microbial protein synthesis in the rumen of cattle receiving grass silage ensiled with different rates of formic acid. Grass Forage Sci. 61:282-292.

Kennedy, P. M., and L. P. Milligan. 1980. The degradation and utilization of endogenous urea in the gastrointestinal tract of ruminants: A review. Can. J. Anim. Sci. 60:205-221.

Lee, M. R. F., L. J. Harris, J. M. Moorby, M. O. Humphreys, M. K. Theodorou, J. C. MacRae, and N. D. Scollan. 2002. Rumen metabolism and nitrogen flow to the small intestine in steers offered Lolium perenne containing different levels of water-soluble carbohydrate. Anim. Sci. 74:587-596.

Licitra, G., T. M. Hernandez, and P. J. Van Soest. 1996. Standardization of procedures for nitrogen fractionation of ruminant feeds. Anim. Feed Sci. Technol. 57:347-358.

McDougall, E. I. 1948. Studies on ruminant saliva. I. The composition and output of sheep's saliva. Biochem. J. 43:99-109.

McManus, M. T., R. L. Bieleski, J. R. Caradus, and D. J. Barker. 2000. Pinitol accumulation in immature leaves of white clover in response to a water deficit. Environ. Exp. Bot. 43:11-18.

Merry, R. J., M. R. F. Lee, D. R. Davies, R. J. Dewhurst, J. M. Moorby, N. D. Scollan, and M. K. Theodorou. 2006. Effects of high-sugar ryegrass silage and mixtures with red clover silage on ruminant digestion. 1 . In vitro and in vivo studies of nitrogen utilization. J. Anim. Sci. 84:3049-3060.

Ministry of Agriculture, Fisheries, and Food. 1984. Energy allowances and feeding systems for ruminants. Reference book no. 433. Her Majesty's Stationery Office, London, UK.

Moorby, J. M., R. T. Evans, N. D. Scollan, J. C. MacRae, and M. K. Theodorou. 2006. Increased concentration of water-soluble carbohydrate in perennial ryegrass (Lolium perenne L.). Evaluation in dairy cows in early lactation. Grass Forage Sci. 61:52-59.

Nolan, J. 1975. Quantitative models of nitrogen metabolism in sheep. Page 416-431 in Digestion and Metabolism in the Ruminant. I. W. McDonald and A. C. I. Warner, ed. University of New England Publishing Unit, Armidale, New South Wales, Australia.

Nousiainen, J., K. J. Shingfield, and P. Huhtanen. 2004. Evaluation of milk urea nitrogen as a diagnostic of protein feeding. J. Dairy Sci. $87: 386-398$

Oldick, B. S., J. L. Firkins, and N. R. St-Pierre. 1999. Estimation of microbial nitrogen flow to the duodenum of cattle based on dry matter intake and diet composition. J. Dairy Sci. 82:1497-1511.

Orr, R. J., P. D. Penning, A. Harvey, and R. A. Champion. 1997. Diurnal patterns of intake rate by sheep grazing monocultures of ryegrass or white clover. Appl. Anim. Behav. Sci. 52:65-77.

Orr, R. J., S. M. Rutter, P. D. Penning, and A. J. Rook. 2001. Matching grass supply to grazing patterns for dairy cows. Grass Forage Sci. 56:352-361. 
Orth, R. 1992. Sample Day and Lactation Report. DHIA 200 Fact Sheet A-2. Mid-States DRPC, Ames, IA.

Papadopoulos, Y. A., and B. D. McKersie. 1983. A comparison of protein degradation during wilting and ensiling of six forage species. Can. J. Plant Sci. 63:903-912.

Peyraud, J. L., L. Astigarraga, and P. Faverdin. 1997. Digestion of fresh perennial ryegrass fertilized at two levels of nitrogen by lactating dairy cows. Anim. Feed Sci. Technol. 64:155-171.

Provenza, F. D., J. J. Villalba, C. D. Cheney, and S. J. Werner. 1998. Self-organization of foraging behaviour: From simplicity to complexity without goals. Nutr. Res. Rev. 11:199-222.

Punia, B. S., J. Leibholz, and G. J. Faichney. 1988. Effects of level of intake and urea supplementation of alkali-treated straw on protozoal and bacterial nitrogen synthesis in the rumen and partition of digestion in cattle. Aust. J. Agric. Res. 39:1181-1194.

Reynal, S. M., and G. A. Broderick. 2005. Effect of dietary level of rumen-degraded protein on production and nitrogen metabolism in lactating dairy cows. J. Dairy Sci. 88:4045-4064.

Reynal, S. M., G. A. Broderick, S. Ahvenjärvi, and P. Huhtanen. 2003. Effect of feeding protein supplements of differing degradability on omasal flow of microbial and undegraded protein. J. Dairy Sci. $86: 1292-1305$.

Rook, A. J., N. H. Lee, and D. J. Armstrong. 1987. The effect of intraruminal infusions of urea, casein, glucose syrup, and a mixture of casein and glucose syrup on nitrogen digestion in the rumen of cattle receiving grass silage diets. Br. J. Nutr. 32:199-208.
SAS Institute. 1999-2000. SAS/STAT User's Guide. Release 8.1. SAS Institute, Cary, NC.

Siddons, R. C., J. Paradine, D. E. Beever, and P. R. Cornell. 1985. Ytterbium acetate as a particulate-phase digesta-flow marker. $\mathrm{Br}$. J. Nutr. 54:509-520.

Smith, A. E., and D. V. Phillips. 1980. Occurrence of pinitol in foliage of several forage legume species. Crop Sci. 20:75-77.

Streeter, J. G., D. G. Lohne, and R. J. Fioritto. 2001. Patterns of pinitol accumulation in soybean plants and relationships to drought tolerance. Plant Cell Environ. 24:429-438.

Titgemeyer, E. C. 1997. Design and interpretation of nutrient digestion studies. J. Anim. Sci. 75:2235-2247.

Trevaskis, L. M., W. J. Fulkerson, and J. M. Gooden. 2001. Provision of certain carbohydrate-based supplements to pasture-fed sheep, as well as time of harvesting of the pasture, influences $\mathrm{pH}$, ammonia concentration and microbial protein synthesis in the rumen. Aust. J. Exp. Agric. 41:21-27.

Tuori, M., A. Vanhatalo, and P. Huhtanen. 2006. Omasal sampling technique in estimation of the site and extent of mineral absorption in dairy cows fed rapeseed and soybean expellers. Agric. Food Sci. 15:219-234.

Udén, P., P. E. Colucci, and S. P. J. Van. 1980. Investigation of chromium, cerium and cobalt as markers in digesta: Rate of passage studies. J. Sci. Food Agric. 31:625-632. 